\title{
Estimation of groundwater recharge in weathered basement aquifers, Southern Zimbabwe; a geochemical approach
}

\author{
David M.J.Macdonald ${ }^{\mathrm{a}}$, W.Mike Edmunds ${ }^{\mathrm{b}}$

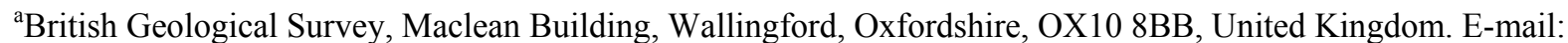 \\ dmjm@bgs.ac.uk, Tel: +44 1491692306 -Corresponding author \\ ${ }^{\mathrm{b}}$ School of Geography and the Environment, University of Oxford, South Parks Road, Oxford, OX1 3QY. E-mail:
wme@btopenworld.com
}

\section{ABSTRACT}

Geochemical techniques have been used to estimate groundwater recharge and its spatial variability in basement terrain in a semi-arid area of southern Zimbabwe. Recharge rates estimated by chloride mass balance have been determined in the Romwe Catchment, a small $\left(4.6 \mathrm{~km}^{2}\right)$ headwater catchment underlain by banded gneisses, with good hydrological and geological control. The results support the findings from piezometric monitoring that there are significant differences in hydrogeological properties of weathered basement derived from different primary lithologies. Annual recharge estimates for shallow weathered aquifers derived from melanocratic bedrock (dominated by pyroxene gneiss), $22 \mathrm{~mm}$, and leucocratic felsic bedrock, $6.7 \mathrm{~mm}$, are $3.7 \%$ and $1.1 \%$ respectively of the long-term mean annual rainfall. The significant uncertainties associated with the chloride mass balance recharge estimates are discussed. Groundwater derived from each lithology generally has a distinctive geochemistry $(\mathrm{Na} / \mathrm{Cl}, \mathrm{K} / \mathrm{Na}, \mathrm{Mg} / \mathrm{Ca}, \mathrm{Na} / \mathrm{Cl}, \mathrm{B}, \mathrm{Ba})$. The information from the Romwe catchment control area was then scaled up using information from remote sensing images (which defined areas of dark and light soils above the banded gneiss) to confirm the higher recharge rates in the melanocratic lithology in the unexplored Greater Romwe $\left(225 \mathrm{~km}^{2}\right)$ area. It is concluded that properly calibrated, remote sensing images could be further regionalized to site groundwater sources in basement terrain, providing a relatively inexpensive development tool.

\section{Introduction}

Groundwater is the main source of water for much of the rural population of sub-Saharan Africa, particularly those in the drought-prone semi-arid regions (Foster et al, 2000; JMP, 2008; MacDonald et al, 2009; MacDonald et al, 2012). The exploitation and sustainability of this resource is key to human survival and economic development. Large areas of sub-Saharan Africa are underlain by crystalline basement rocks and much research has been undertaken on groundwater storage and flow within this aquifer and how best to develop and protect water supplies (e.g. Wright, 1992; Chilton and Foster; 1995, MacDonald et al; 2005).

Crystalline basement rock in Africa is primarily of Precambrian age and granitic or gneissose in type (Clark, 1985). Basement aquifers are formed due to the effects of prolonged weathering and tectonic forces on the parent rock (Fookes, 1997). The aquifer can be simplified to a two layer system: the shallow weathered layer (regolith), and the underlying largely unweathered bedrock (Acworth, 1987). The regolith has a high storage in comparison with the bedrock; fractures within the bedrock provide permeability which can be high where a significant network of fractures exists (Chilton and Foster, 1995; Taylor et al, 2010). Boreholes completed in the bedrock are particularly productive where the fractures tap a large volume of overlying saturated regolith. The degree of weathering of the basement rock is dependent on a number of factors including: the mineralogy and texture of the parent rock (Jones, 1985; Courtois et al, 2010); fracturing that has occurred within the parent rock; the age of the erosion surface (Taylor and Howard 2000); and the quantity of groundwater recharge and throughflow (Jones, 1985; Acworth, 1987). The weathering profile may vary considerably both on a regional and local scale.

An investigation of the control this variability in weathering can have on groundwater recharge and well productivity was undertaken between 1993 and 1998 as part of the work undertaken in southern Zimbabwe within the Romwe Catchment Study (RCS; Bromley et al, 1999). The Romwe catchment is a small basement-complex headwater catchment lying within the northern margins of the Limpopo Mobile Belt (Robertson, 1974). An aim of the RCS was to improve the understanding of hydrological processes, and 
particularly groundwater recharge mechanisms, in areas of crystalline basement geology having a land use typical of communal lands. A number of studies relevant to understanding the groundwater system within the RCS have been published (Macdonald et al, 1995; Butterworth, 1997; Bromley et al, 1999; Butterworth et al, 1999abc; Moriarty, 2000).

The main objective of the study reported here was to investigate the use of chloride as a tool for estimating groundwater recharge in basement terrains. This technique has been successfully applied to sedimentary areas with deep unsaturated zones, such as in Australia (Allison et al, 1994), Senegal (Gaye and Edmunds, 1996) and China (Gates et al, 2008) but its application to basement areas and the weathered regolith has received little attention (Lapworth et al, 2013). In this paper, as well as $\mathrm{Cl}$, major ions are used to characterize the hydrogeochemistry so as to infer the predominant aquifer units. The conclusions from work undertaken within the $4.6 \mathrm{~km}^{2}$ Romwe catchment, used as a control, were applied to a larger area of $225 \mathrm{~km}^{2}$ (Greater Romwe) to evaluate geochemical methods and remote sensing as tools for regional groundwater exploration. As well as addressing a gap in knowledge on the hydrogeological behaviour of basement aquifers, this study contributes towards the challenge of meeting the water requirements of rural populations in hard rock terrain.

\section{Background}

\subsection{Romwe Catchment Study}

The Romwe catchment is located in the Save River Basin, within the northern margins of the Zimbabwean Lowveld, at an altitude of $\sim 800 \mathrm{~m}$ asl. The site $\left(20^{\circ} 45^{\circ} \mathrm{S}, 30^{\circ} 46{ }^{\circ} \mathrm{E}\right)$ is $390 \mathrm{~km}$ south of Harare (Figure 1). The catchment (Figure 1) which had a dispersed population of 200-250 at the time of the study ( 49 persons $/ \mathrm{km}^{2}$ ), is typical of many headwater catchments in the communal lands of Zimbabwe, in that it is underlain by crystalline basement and has mixed land use consisting of rainfed farming and woodland vegetation. Gentle slopes along the valley floor, drained by an ephemeral stream, are flanked by steep rocky hills, dissected at intervals by steep saddles. Cultivation is restricted to the valley floor, while steep valley sides are covered by Miombo woodland (Cowling et al, 1997). Rainfall usually occurs only in the summer months from October to April. The annual average rainfall is $591 \mathrm{~mm}$ (std dev $253 \mathrm{~mm}$ ), based on a 45 year record at Chendebvu Dam (Mugabe et al, 2007), $12 \mathrm{~km}$ to the north of the catchment; the inter-annual variability for this period ranges from $83 \mathrm{~mm}$ to $1191 \mathrm{~mm}$. The annual rainfall measured in the Romwe Catchment over the period of the study was: 1993/94, $538 \mathrm{~mm}$; 1994/95, $501 \mathrm{~mm}$; 1995/96, $866 \mathrm{~mm}$; 1996/97, 719; 1997/98, $673 \mathrm{~mm}$.

The Romwe catchment is located in an area of strongly-banded granulite gneiss (Bromley et al, 1999). The gneissic foliation dominates the trend of the topography in the catchment (Figures 1 and 2). The gneisses range from dark-coloured pyroxene gneisses to light-coloured quartzo-feldspathic granulites. Between these extremes of composition is a wide range that grades imperceptibly from one to the other. The various types are interbanded at scales from a few centimetres to several hundred metres, however, the north side of the low-lying cultivated areas of the catchment is dominated by melanocratic pyroxene gneisses, while leucocratic pyroxene gneisses banded together with subordinate amounts of quartzo-feldspathic gneiss are more common on the southern side (Bromley et al, 1999). The high ground within the catchment is primarily quartzo-feldspathic gneisses with subordinate pyroxene amphibolite and biotite gneisses although this also underlies some of the lower-lying cultivated areas in the south of the catchment. Within the leucocratic pyroxene gneisses, pyroxene is usually the dominant mafic mineral though occasionally amphiboles or biotite may be more abundant; these mafic minerals constitute up to $25 \%$ of the rock. Hypersthene is the dominant mafic mineral in the pyroxene gneisses, often forming up to $70 \%$ of the rock.

The geology strongly controls the distribution of soil types in the catchment. Two main soil types are present (Bromley et al, 1999). In the low-lying cultivated land on the southern side of the main catchment stream, there is a grey duplex soil (ferric lixisols) of sandy loam, 0.3 to $1 \mathrm{~m}$ thick. This is coincident with the leucocratic gneiss but also with the lower lying areas mapped as predominantly quartzo-feldspathic gneiss. For the majority of the area where the grey duplex soil occurs it is underlain by a sandy clay layer. The leucocratic gneiss and quartzo-feldspathic gneiss from hereon will be referred to as the "felsic" rock group. In the low-lying areas to the north of the stream, the less resistant and more easily weathered melanocratic pyroxene gneiss (referred to hereon as "mafic rock") has given rise to red clay soils (chromic lixisols). The 
distinction between the red mafic rocks and grey-coloured felsic-rock group is strong when viewed in aerial photography.

Field studies (Butterworth et al, 1999b; Moriarty, 2000) have identified significant differences in the properties and hydrological regimes associated with the mafic and felsic soils and rocks. Based on data from two representative sub-catchments, Butterworth et al (1999a) showed runoff to be greater on the felsic soils than the mafic soils by a factor of six and five respectively in seasons $1994 / 5$ and $1995 / 6$. This is a combination of: the crusting that develops on the felsic soils during dry periods; the saturated near-surface conditions that develop during wet periods; and the thick clayey horizon within the weathered zone of the felsic rocks which promotes interflow.

Groundwater levels indicate that groundwater flow follows the topographic slope towards the stream, that flows through the centre of the catchment, and towards the catchment outlet to the west. In estimating groundwater recharge Moriarty (2000) differentiates between the felsic rock areas where the soil is underlain by the clay layer and the remainder of low-lying areas of the catchment which are dominated by the mafic rocks. He estimated annual groundwater recharge to the felsic rock aquifer where underlain by the clay layer for the period 1993/94 to 1997/98, using the water table fluctuation method (Crosbie et al, 2005), to be typically half that elsewhere in the low-lying areas of the catchment. The total groundwater recharge calculated using this method ranged from $24 \mathrm{~mm}$ in 1994/95 to $188 \mathrm{~mm}$ in 1996/97. Butterworth et al (1999a) identify rainfall distribution within a season as important, with recharge being highly dependent on the occurrence of intense rainfall events. They also highlight the value of management structures, in particular contour bunds, which hold up runoff and promote recharge.

The groundwater level fluctuation within the weathered zone of the mafic rocks and felsic rock group is significantly different as shown by two representative groundwater hydrographs (Figure 3). The rise and subsequent recession of groundwater levels in the mafic rocks is greater than in the felsic rock group. For example, as a result of the rainfall season in 1995/96, groundwater levels in the mafic rocks typically rose by $7 \mathrm{~m}$. This compared with a typical rise of $3 \mathrm{~m}$ in the felsic rock group for the same rainfall season.

Pumping tests undertaken by Macdonald et al (1995) show the weathered zone of the mafic rocks to be more permeable than that of the felsic rock group. Although variable across the catchment, there is no significant difference in the depths of the weathered zone between the mafic rocks and the felsic rock group; the typical depth of the weathered profile is $12 \mathrm{~m}$. Figure 4 illustrates the influence of the weathered profile on well productivity in the Romwe Catchment. The figure shows water levels in domestic wells completed in the mafic (Well 6, Figure 4a) and felsic (Well 10, Figure 4b) rocks and in piezometers located in the vicinity (a distance of $138 \mathrm{~m}$ and $168 \mathrm{~m}$, respectively); weekly abstraction volumes are also shown. The pumping tests gave transmissivities of $1.99 \mathrm{~m} 2 / \mathrm{d}$ for the well in the mafic rock and $0.22 \mathrm{~m} 2 / \mathrm{d}$ for the well in the felsic rock (Macdonald et al, 1995). A notable drawdown occurs in the latter over the period June 1994 to October 1995 $(\sim 9 \mathrm{~m})$ in response to an average daily abstraction of 118 litres. This compares with the well in the mafic rock which shows only a small drawdown in response to an average daily abstraction of 411 litres over the same period.

Prior to the rainy season of 1995/96 there had been almost a decade of below average rainfall in the region. In the latter two seasons of this period, during which monitoring took place in the catchment, groundwater levels started and ended the season close to the base of the weathered aquifer (Butterworth et al, 1999b; Figure 3). In the subsequent three years, groundwater levels at the end of the dry season rose each year as a result of above average rainfall (Figure 3). Bedrock outcrops across the majority of the outlet of the Romwe catchment. Moriarty (2000) identifies the primary mechanisms for groundwater discharge from the catchment as transpiration by deeply-rooted vegetation located in the valley bottom and lateral groundwater flow from the catchment to the west through the bedrock.

\subsection{Recharge investigations using hydrogeochemical methods}

Physical approaches in the past have been more widely used than tracer (isotopic and chemical) techniques for recharge estimation (eg Simmers, 1988; Lerner et al, 1990). In semi-arid regions however, there is recognition of the limitations of the physical approaches (Allison et al, 1994). Studies of the unsaturated zone using chemical or isotopic techniques in particular are considered to offer definite advantages over physical approaches and 
recently the use of CFCs and $\mathrm{SF}_{6}$ have been shown as promising tools for identifying modern recharge and infiltration rates (Stadler et al 2010; Lapworth et al, 2013). Profile techniques using tritium or $\mathrm{Cl}$ in unsaturated zones of predominantly sandy terrain (Scanlon et al, 2006) have now been successfully applied in many areas: Africa (Edmunds et al, 1988; Gaye and Edmunds, 1996), Middle East (Edmunds and Walton, 1980), Australia (Allison and Hughes, 1978), India (Sukhija et al, 1976), North America (Phillips, 1994; Wood and Sandford, 1995) and China (Gates et al, 2008), and generally provide realistic mean recharge estimates over periods of years or decades. Of the three widely used tracer methods (tritium, stable isotopes and $\mathrm{Cl}$ ) $\mathrm{Cl}$ proves especially attractive as a low-cost tracer for recharge estimation in rural, often remote areas (Edmunds and Gaye, 1994). In semi-arid areas, $\mathrm{Cl}$ has the advantage over tracers involving the water molecule $\left({ }^{3} \mathrm{H}, \delta^{18} \mathrm{O}, \delta^{2} \mathrm{H}\right)$ in that atmospheric $\mathrm{Cl}$ inputs are conserved during the recharge process, allowing a mass balance approach to be adopted.

Determining the spatial variability of groundwater recharge remains a challenge but chemical methods can offer a simple and cost-effective solution. Work by Eriksson and Khunakasem (1969) and Eriksson (1976) showed that $\mathrm{Cl}$ in groundwaters could be used to provide regional estimates of recharge provided there is no geological input, and if atmospheric deposition of $\mathrm{Cl}$ is known. The chloride mass balance (CMB) has been used to determine the spatial variability of recharge in Senegal (Edmunds and Gaye, 1994), extrapolating the unsaturated zone data using shallow wells. The present study is an attempt to apply the CMB approach to basement terrain with deeply weathered regolith.

The basic approach for using $\mathrm{Cl}$ to estimate groundwater recharge relates to the partitioning of precipitation:

$\mathrm{P}=\mathrm{E}+\mathrm{R}+\mathrm{Q}$

where $\mathrm{P}=$ precipitation

$\mathrm{E}=$ evapotranspiration from soil and shallow root zone

$\mathrm{R}=$ recharge to groundwater

$\mathrm{Q}=$ surface runoff to streams

If it is assumed $\mathrm{Cl}$ is neither gained nor lost via weathering, we can include $\mathrm{Cl}$ concentrations in Eq. 1:

$\mathrm{P} * \mathrm{Cl}_{\mathrm{pptn}}=\mathrm{E}^{*} \mathrm{Cl}_{\text {evap }}+\mathrm{R} * \mathrm{Cl}_{\text {rec }}+\mathrm{Q} * \mathrm{Cl}_{\text {roff }}$

where $\mathrm{Cl}_{\mathrm{pptn}}=$ chloride concentration in precipitation

$\mathrm{Cl}_{\text {evap }}=$ chloride concentration in evapotranspiration

$\mathrm{Cl}_{\text {rec }}=$ chloride concentration in groundwater recharge

$\mathrm{Cl}_{\text {roff }}=$ chloride concentration in surface runoff

The term $\mathrm{Cl}_{\mathrm{pptn}}$ includes both wet and dry deposition during the rainy season but excludes any aerosol deposited during the dry season. If $\mathrm{Cl}_{\text {evap }}$ is zero and $\mathrm{Cl}_{\text {roff }}$ assumed equal to $\mathrm{Cl}_{\text {pptn }}$, Eq. 2 can be reduced and rearranged to give $\mathrm{R}$ :

$\mathrm{R}=(\mathrm{P}-\mathrm{Q}) *\left(\mathrm{Cl}_{\mathrm{pptn}} / \mathrm{Cl}_{\mathrm{rec}}\right)$

Eq. 3 is applied within the Romwe catchment. The appropriateness of the assumptions made is explored in the Section 5.

\section{Methods}

The applicability of the CMB method was tested in the Romwe catchment where it could be validated with estimates of recharge made using physical methods (Butterworth et al, 1999ab). The method was then scaled up to the much larger area of Greater Romwe in which more limited data were available on the hydrogeology. Here, groundwater chemistry was used as a means to verify the hypothesis that soils are good indicators of underlying geology. The CMB method was then used as a means to assess the spatial variation in groundwater recharge in Greater Romwe. 
The study was undertaken between April 1993 and March 1997. Within the Romwe catchment, as part of the overall Romwe Catchment Study, an instrument network was established to measure rainfall, surface run-off, soil moisture storage, soil and plant evaporation, groundwater recharge and groundwater flow. During the period from November 1993 to October 1996, three full hydrological seasons, rainfall was measured and rainfall samples, representing total deposition, collected and analysed for $\mathrm{Cl}$. Rainfall samples were taken on an event basis when a measurable amount of rainfall had occurred, normally greater than $1 \mathrm{~mm}$.

To allow groundwater level fluctuation to be monitored, a total of 65 piezometers had been drilled in and around the catchment (Figure 1). The depths of the majority of the piezometers were determined by the extent of the weathered zone, with completion depths being approximately one metre into the bedrock. Depths range from 2.5 to $20.3 \mathrm{~m}$ (Table 1). All the piezometers have casing within the first metre of the ground surface but are open hole below this depth. Groundwater levels were also measured in 34 of the traditional hand-dug wells in the Romwe catchment and in one domestic borehole (Well 15). The wells ranged in depth from 3.6 to $12.6 \mathrm{~m}$; the borehole was $45 \mathrm{~m}$ deep. Groundwater levels were measured on a weekly basis increasing in frequency to daily after a major $(>30 \mathrm{~mm})$ rainfall event.

Groundwater samples were taken in March 1994 from the 35 traditional wells and a selection of 40 of the piezometers. A number of the shallow piezometers were dry; those chosen from the remaining piezometers provided a good spatial distribution of sampling points. Samples were pumped using a small capacity battery-driven pump (10 litres $\left.\mathrm{min}^{-1}\right)$. A volume of water equivalent to three times that within the piezometer was pumped before sampling; this was not possible for the large-diameter wells. All groundwater samples were filtered in the field using $0.45 \mu \mathrm{m}$ membrane filters and analysed for major and selected minor elements ( $\mathrm{Na}, \mathrm{K}, \mathrm{Ca}, \mathrm{Mg}, \mathrm{Sr}, \mathrm{Ba}, \mathrm{B}$, and $\mathrm{Si}$ ) using ICP-OES and automated colorimetry for $\mathrm{Cl}, \mathrm{F}, \mathrm{NO}_{3}$ and I. Apart from 12 samples, ionic balances were within $\pm 12 \%$. The 18 wells and boreholes in areas where the underlying bedrock geology is unclear are not included in Table 1; the sites of wells and boreholes are overlain on the geology map in Figure 2.

Subsequently a number of elements were monitored in six wells and two piezometers in the Romwe catchment during the dry season of 1996, to assess the difference between the two lithologies in terms of the changes in groundwater chemistry with time. Samples were taken initially on a weekly and then a monthly basis. This was used to improve the understanding of recharge processes and to inform the timing of sampling in the Greater Romwe element of the study.

The CMB method, given assumptions made in Eq. 3, requires an estimate to be made of the surface runoff (Q). Q was measured in two sub-catchments within the Romwe Catchment (Bromley et al, 1999), representative of the red clay soils and the grey duplex soils across the whole of the catchment. It was only possible to collect a small number of runoff samples to measure $\mathrm{Cl}$ concentrations, which was not sufficient to estimate a mean $\mathrm{Cl}$ concentration of this component of the mass balance.

Prior to this study, limited information was available outside of the Romwe catchment. A larger area (225 $\mathrm{km}^{2}$ ) centred on the Romwe catchment, here termed Greater Romwe, was used to test the hypotheses developed within Romwe (Figure 5). The physical and socio-economic characteristics of Greater Romwe are comparable to those in the Romwe catchment although Romwe appears to have a higher degree of cultivation than elsewhere in Greater Romwe. A field survey was undertaken in the Greater Romwe area to identify wells and boreholes which were well distributed and had headworks protecting them from direct contamination from activities on the surface. A total of 55 sites were identified. At each site information was gathered on the groundwater source and a survey undertaken of soil type in the vicinity. Subsequently a oneoff groundwater sampling campaign was undertaken between September and November 1997 at the end of the dry season. The procedure and range of analyses undertaken on the groundwater samples were the same as those used within the first phase of the study within the Romwe Catchment.

Figure 5 shows major soil types for the Greater Romwe area, based on a Landsat (Rocchio, 2011) satellite image (30 x $30 \mathrm{~m}$ pixel) taken in November 1992, during a period of severe drought. The lack of vegetation cover during this period gives above-average soil visibility. The pixels with bands associated with bare rock and the vegetation that cover high ground have been plotted in white to simplify the image (this also gives an indication of the relief of the area). What remain are pixels with bands coinciding with low-lying areas. 


\section{4. $\quad$ Results}

\subsection{Geochemical signatures in groundwater in Romwe Catchment}

The chemistry of groundwater in the Romwe catchment is presented in Table 1, sub-dividing samples occurring in the areas with the red clay soils overlying the mafic rocks and those in the areas with the grey duplex soils overlying the felsic rock group. As already mentioned, those in areas where the underlying bedrock geology is unclear are not included in Table 1.

The groundwater mineralisation can be regarded mainly as the result of evaporative concentration combined with weathering reactions with rock forming minerals and soil derivatives (Appelo and Postma, 2005). Silicate mineral weathering of the felsic and mafic components of the gneisses involves hydrolysis of the primary mineral to produce a secondary clay mineral, Si and major cations and substituted trace elements. This can be expressed most simply as:

a) weathering of feldspar (example of albite)

$\underset{\text { albite }}{2 \mathrm{Na}\left(\mathrm{AlSi}_{3}\right) \mathrm{O}_{8}}+2 \mathrm{H}^{+}+9 \mathrm{H}_{2} \mathrm{O} \rightarrow \underset{\text { kaolinite }}{\mathrm{AlSi}_{2} \mathrm{O}_{5}(\mathrm{OH})_{4}}+2 \mathrm{Na}^{+}+4 \mathrm{H}_{4} \mathrm{SiO}_{4}$

b) weathering of mafic minerals (biotite and pyroxene)

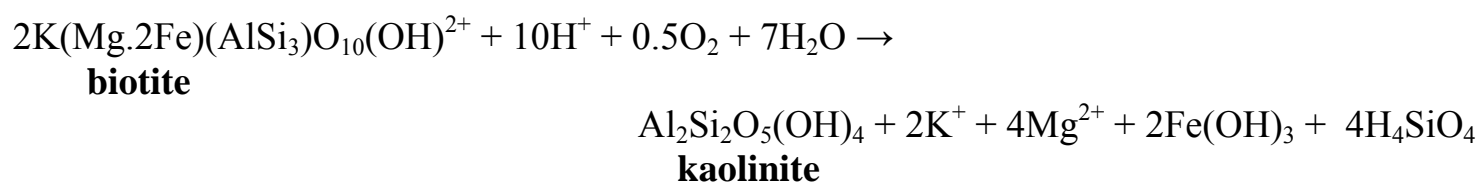

$$
\underset{\text { pyroxene }}{\left(\mathrm{Mg}_{0.7} \mathrm{CaAl}_{0.3}\right)\left(\mathrm{Al}_{0.3} \mathrm{Si}_{1.7}\right)} \mathrm{O}_{6}+3.4 \mathrm{H}^{+}+1.1 \mathrm{H}_{2} \mathrm{O} \rightarrow \underset{\text { kaolinite }}{.3 \mathrm{Al}_{2} \mathrm{Si}_{2} \mathrm{O}_{5}(\mathrm{OH})_{4}}+\mathrm{Ca}^{2+}+0.7 \mathrm{Mg}^{2+}+1.1 \mathrm{H}_{4} \mathrm{SiO}_{4}
$$

In the felsic gneiss, $\mathrm{K}$-feldspar (orthoclase) and/or albite may be present and $\mathrm{K} / \mathrm{Na}$ ratios will vary accordingly. In the mafic gneisses, pyroxene (hypersthene) where present would contain mainly $\mathrm{Fe}$ and $\mathrm{Mg}$ with trace $\mathrm{Ca}$; hornblende may also be present as an alternative mineral phase giving rise to $\mathrm{Mg}$ and $\mathrm{Fe}$ as solutes. There is also the possibility for a wide range of alternative secondary clay minerals.

The inorganic (cation) chemistry is summarised in a trilinear plot (Figure 6). This plot uses only those samples that can be clearly associated with underlying mafic or felsic group rocks (see Table 1) and had acceptable ionic balances (within $\pm 12 \%$ ). In Figure 6 the overall mafic (pyroxene gneiss) weathering contribution is seen in the bulk of samples having $\mathrm{Mg} / \mathrm{Ca}$ considerably above 1 , reflecting this major source of $\mathrm{Mg}$ as compared with the lower $\mathrm{Mg} / \mathrm{Ca}$ ratios in the felsic group which only contain minor amounts of mafic minerals. $\mathrm{Na}$ and $\mathrm{K}$ are predominantly enriched in groundwaters from the felsic group containing a predominance of plagioclase and K-feldspar. High concentrations of Si (24 and $20 \mathrm{mg} \mathrm{l}^{-1}$, respectively) in both mafic and felsic groups reflect the weathering process. Other important results include the low $\mathrm{F}$ concentrations showing that, unlike many hard rock regions, F enrichment is not prevalent. Iodide was investigated as a possible tracer but results were inconclusive.

Groundwater $\mathrm{Cl}$ concentrations range from 6.1 to $910 \mathrm{mg} \mathrm{l}^{-1}$. Human activities would tend to concentrate $\mathrm{Cl}$ already in the catchment and any adjustments to the mass balance due to import from outside the catchment (eg food) are likely to be small. Nitrate concentrations in most groundwaters are high. The presence of $\mathrm{NO}_{3}$ indicates that largely aerobic conditions are likely to prevail and this is backed up by the mainly very low concentrations of dissolved iron (Table 1). The high $\mathrm{NO}_{3}$ concentrations may in part be a natural phenomenon, due to N-fixing vegetation (Edmunds and Gaye, 1997) although addition from human activity (Malomo et al, 1990; Taylor and Howard, 1995) is considered more likely to account for high $\mathrm{NO}_{3}$ in some of the wells and piezometers. Groundwaters in Romwe have higher overall $\mathrm{NO}_{3}$ concentrations than in Greater Romwe, likely due to the more intensive cultivation in Romwe. To reduce uncertainty, samples with over $20 \mathrm{mg} \mathrm{l}^{-1} \mathrm{NO}_{3}-\mathrm{N}$ are excluded from the data set for discussion of recharge. The influence of 
groundwater irrigation returns on groundwater $\mathrm{Cl}$ concentrations is minimal as this is limited to a small number of market gardens.

Taking $\mathrm{Cl}$ as a conservative tracer and recharge indicator, a series of plots of ions and ionic ratios (Figure 7) are then used to investigate lithology origins and whether the field classifications of soil/rock types are matched by the geochemical characteristics of the groundwaters. It is evident that the geochemical signatures must be established rapidly during the infiltration process. The $\mathrm{Na} / \mathrm{Cl}$ plot (Figure 7 ) shows that waters from the mafic group generally have lower $\mathrm{Cl}$ than the felsic group. The spatially-averaged $\mathrm{Cl}$ concentrations from groundwaters in the two rock types, estimated by interpolation onto a regular grid using kriging, are 24.1 $\mathrm{mg} \mathrm{l}^{-1}$ for the mafic rock and $74 \mathrm{mg}^{-1}$ for the felsic rock group. Based on a Mann-Whitney test, the mean $\mathrm{Cl}$ concentrations in the two geologies are shown to be signficantly different ( $p=0.0004$ for the null hypothesis). This indicates lower amounts of recharge in the felsic rock group (n.b. all the groundwater samples from the felsic rock group apart from three came from the areas where the shallow clay layer is present). The $\mathrm{Na} / \mathrm{Cl}$ ratio vs $\mathrm{Cl}$ also shows that both groups are enriched in $\mathrm{Na}$ with ratios usually between 1 and 4, likely due to the weathering of plagioclase. Barium is higher in the felsic group indicating the likely contribution of Kfeldspar with $\mathrm{Ba}$ as a trace constituent. The $\mathrm{Sr} / \mathrm{Ca}$ ratio is also greater in the felsic group which may relate to the higher abundance of $\mathrm{K}$-feldspar in which $\mathrm{Sr}$, like $\mathrm{Ba}$, may occur as a trace element. The $\mathrm{K} / \mathrm{Na}$ ratio is higher in the mafic group which indicates a greater relative release of $\mathrm{K}$ in this group (from $\mathrm{K}$-feldspar and especially biotite) than in the felsic rocks. Boron was investigated as a tracer but no significant lithological differences were found.

\subsection{Trends in groundwater chemistry}

Groundwater chemistry in a series of eight wells and piezometers in the Romwe catchment was monitored throughout the 1995/96 dry season. The chemical responses of two wells (Well 2, representative of the mafic rocks, and Well 11, of the felsic group) are shown in Figure $8 . \mathrm{Ba}, \mathrm{Sr} / \mathrm{Ca}, \mathrm{Mg} / \mathrm{Ca}$ and $\mathrm{Cl}$ are selected to illustrate trends.

There is a clear separation between the two lithologies as shown by $\mathrm{Ba}$ and the $\mathrm{Mg} / \mathrm{Ca}$ and $\mathrm{Sr} / \mathrm{Ca}$ ratios. High $\mathrm{Mg} / \mathrm{Ca}$ ratios characterise waters from the mafic gneiss, and higher $\mathrm{Sr} / \mathrm{Ca}$ ratios as well as $\mathrm{Ba}$ in the felsic lithology are consistent with greater contribution from weathering of K-feldspar. The relatively uniform ratios throughout the recession period indicated that there is no contribution from other lithologies or sources. The lower $\mathrm{Cl}$ values are further evidence of the higher recharge through the red soils overlying the mafic rocks. Overall there are very slight increases observed in $\mathrm{Cl}$ (and the other tracers) throughout the season in most groundwaters but these are more marked in the wells in the felsic rock group. The water chemistry at the beginning of the dry season in the wells and piezometers in the felsic rock group is thought to be affected by direct recharge from interflow at the base of the sandy surface layer. The water chemistry slowly stabilises through mixing and reaction to that representative of the aquifer during the dry season.

\subsection{Chloride mass balance for Romwe Catchment}

The weighted mean rainfall Cl concentrations in the three seasons 1993/94, 1994/95 and 1995/96 were 0.78, 1.39 and $0.68 \mathrm{mg}^{-1}$ respectively, and $0.89 \mathrm{mg} \mathrm{l}^{-1}$ (std dev $0.42 \mathrm{mg} \mathrm{l}^{-1}$ ) for the three year period. The rainfall $\mathrm{Cl}$ concentrations for a missing period between February and April 1994 were estimated using daily volume and $\mathrm{Cl}$ concentration ratios for the rainfall from the rest of that wet season.

The $\mathrm{CMB}$ method compares the $\mathrm{Cl}$ entering the ground with an averaged $\mathrm{Cl}$ concentration in the groundwater. Piezometric data indicate that there is no lateral inflow of groundwater to the catchment. To calculate the mass of $\mathrm{Cl}$ entering the ground the effective rainfall must be known. This is calculated by subtracting the runoff component from the rainfall (the complications of interflow or deep outflow are ignored here). The long-term annual effective rainfall on each soil type was approximated using the longterm average annual rainfall (591 mm, from Chendebvu Dam) and the runoff for the 1995/96 wet seasons on the representative sub-catchments in Romwe (Bromley et al, 1999). It is recognized that the relationship between the long-term average rainfall and runoff is unlikely to be linear. To calculate a mean groundwater recharge, the effective rainfall was used along with the spatially-averaged groundwater $\mathrm{Cl}$ concentrations for 1994/95. The stages of the calculation are shown in Table 2. The groundwater recharge of $22 \mathrm{~mm}$ calculated for the mafic aquifer compares well with the estimates of $24 \mathrm{~mm}$, made separately, by Butterworth et al 
(1999a) and Moriarty (2000) for 1994/95 for the areas of the catchment not underlain by the thick clay layer; they used soil moisture balance and water table fluctuation methods, respectively. The recharge of $6.7 \mathrm{~mm}$ calculated for the felsic aquifer using the CMB method does not compare as well with that of $14 \mathrm{~mm}$ made by Moriarty (2000) using the water table fluctuation method for the areas underlain by the thick clay layer, however, it does support the finding that the recharge here is substantially lower.

\subsection{Greater Romwe study}

Having developed a hydrogeochemical model within the Romwe catchment, its validity was then tested on the larger area of Greater Romwe for which little information on agriculture or water supply was previously available. Physically, the Romwe Catchment typifies the topography, geology and soil types of the Greater Romwe area, apart from the relief of the north-eastern zone which is much lower. Information on the water resources within the Greater Romwe area, outside of the Romwe catchment, is only anecdotal. It suggests that water availability is lower in the west and south-west of the area. There are very few wells in this area, with most of the population relying on a limited number of boreholes or sandholes in the river beds.

Fifty-five groundwater sources were sampled in Greater Romwe of which 35 were traditional hand-dug wells and 20 were boreholes. The wells were typically six metres in depth, with a diameter of two metres. Limited information was available on borehole depths; owners reported depths between 25 and 46 metres. It was not possible to measure the depth to the water table in all the sources, in particular in the boreholes, however, where measured this ranged from 0.5 to $6.3 \mathrm{~m}$ from ground surface. Boreholes were fitted with handpumps while water was abstracted from the majority of hand-dug wells by bucket. Almost all the groundwater sources were used for domestic supply while water from approximately half of the wells was used for other purposes such as small-scale irrigation, livestock watering and brick making.

The two predominant bands of the Landsat satellite image match well with the two soil types mapped in the low-lying cultivated areas in the Romwe catchment. At 43 of the 55 groundwater sources sampled as part of the Greater Romwe study it was possible to identify clearly a soil type and at these sites there was a good match with soil type inferred from the Landsat satellite image (Figure 5). It is therefore assumed that Figure 5 provides a good approximation of a simplified soil map for Greater Romwe. This shows that the grey duplex soils predominate in the Greater Romwe area. The most detailed geology map covering Greater Romwe (Robertson, 1974; 1:150,000) does not delineate the mineralogical variation in the basement gneiss.

Analysis of groundwater chemistry in the Greater Romwe area focusses on those 43 wells and boreholes referred to above. It is assumed that borehole water is representative of the groundwater in the regolith at that location; if the borehole is tapping the fractured bedrock its low storage would mean it is being continually replenished by the regolith water. The chemistry of groundwaters sampled in November 1997 is presented in Table 3. As with the Romwe catchment data, a series of plots of ions and ionic ratios $(\mathrm{Na}, \mathrm{Na} / \mathrm{Cl}, \mathrm{K} / \mathrm{Na}$, $\mathrm{Mg} / \mathrm{Ca}, \mathrm{Sr} / \mathrm{Ca}$ and $\mathrm{Ba}$ ) versus $\mathrm{Cl}$ are shown (Figure 9). The correlation of geology and soil type identified in the Romwe Catchment was extrapolated to Greater Romwe and the geology associated with each of the sampling points was inferred from the soil type at the location of the groundwater source.

One main difference in the chemistry in the Romwe catchment and in Greater Romwe is the lower concentration of $\mathrm{NO}_{3}$ in the latter, with a large numbers of samples with $\mathrm{NO}_{3}$ below limits of detection. It may be inferred that the greater level of agricultural activity in the Romwe catchment is a major control. An alternative explanation is that the groundwater use has not been as great and that with longer residence time there has been some denitrification.

The same overall geochemical ratios are again seen, differentiating the two main rock types as in Romwe. As with the Romwe catchment, the $\mathrm{Cl}$ concentrations are, in general, significantly higher in the felsic rock group, indicating a lower overall recharge. The spatially-averaged $\mathrm{Cl}$ concentration in Romwe of $\sim 1: 3.2$ (mafic to felsic) compares with the ratio of medians of $\sim 1: 2.1$ in Greater Romwe. The median $\mathrm{Cl}$ concentrations in the mafic and felsic group in the Greater Romwe groundwaters are both lower than in the Romwe catchment. This may be related to the relatively high period of rainfall that occurred between Romwe (1994) and Greater Romwe (1997) sampling campaigns. 


\section{Discussion}

\subsection{Geochemical signatures}

The geochemical data on the groundwaters in the Romwe catchment show distinctive signatures for waters derived from each of the two main lithological groups. Groundwaters from the mafic rocks are distinguishable by lower $\mathrm{Na} / \mathrm{Cl}, \mathrm{Sr} / \mathrm{Ca}$ and higher $\mathrm{Mg} / \mathrm{Ca}$ compared to those derived from the felsic rock group. The classification of rock types in the catchment made from the field observations is borne out largely by the geochemical signatures, which are established rapidly on infiltration. This subdivision is remarkably clear given the complex nature of bedrock geology in a high grade metamorphic terrain such as this. Some of the departures from the overall classification must relate to three-dimensional geological features including facies variations. In Greater Romwe the geochemical signatures give confidence in the use of the Landsat satellite image as a means to determine aquifer type.

\subsection{Recharge estimation from $C M B$}

In this study the main application of the CMB method has been to draw attention to the control of bedrock lithology on relative magnitudes of groundwater recharge and validate these using the physical estimates. In assessing the uncertainty in the absolute and relative estimates of recharge made, it is necessary to examine the assumptions made in applying the method to the Romwe catchment and Greater Romwe:

i) Conservation of atmospheric and soil Cl. Total (wet and dry) deposition was measured over the rainy season, as in previous studies (Gaye and Edmunds, 1996). Dry deposition outside the rainy season was not measured, and assumed not to form a significant contribution; if it were, then this would mean recharge calculated here is an underestimate. In dryland areas there is the potential for soil erosion and $\mathrm{Cl}$ export but in Romwe the vegetated surface greatly restricts any wind erosion.

ii) Addition of $\mathrm{Cl}$ from geological sources. Compared with other inorganic ions, $\mathrm{Cl}$ is inert, and with very few exceptions is neither being added nor removed by water-rock interaction during percolation in the vast majority of environments. Primary minerals in igneous and metamorphic terrain can be a source of $\mathrm{Cl}$, substituting for $\mathrm{OH}$ as a trace constituent of biotite and amphiboles especially in volatile-rich igneous rocks (Edmunds et al, 1984; Kamineni, 1987). However, in high grade metamorphic terrain, such as within the Greater Romwe area, it is likely that primary minerals have undergone extensive alteration and any $\mathrm{Cl}$ substituted by $\mathrm{OH}$.

iii) Influence of vegetation. Vegetation removes water by evapotranspiration but retains $\mathrm{Cl}$ and is expected to show steady state behaviour unless widescale vegetation clearance takes place; xylem water in trees, for example, largely reflects that of the soil solution (Raveh and Levy, 2005). Thus, $\mathrm{Cl}$ will be recycled in the soil and as decaying vegetation although may be exported as biomass. Some water loss (and $\mathrm{Cl}$ concentration) by evapotranspiration from deep-rooted vegetation from shallow water tables is possible (Moriarty 2000). In Romwe, however, the areas occupied by such vegetation are located primarily outside and downstream of the cultivated zones where groundwater is sampled.

iv) Human influence on $\mathrm{Cl}$. High groundwater $\mathrm{NO}_{3}$ concentrations, such as were found in many of the sites across Romwe, can be associated with high $\mathrm{Cl}$. In Romwe, high $\mathrm{NO}_{3}$ may be the result of organic fertilizers (artificial inorganic fertilizers are not routinely used) which would not add significant amounts of $\mathrm{Cl}$ or $\mathrm{N}$-fixing by leguminous plants which also would not add $\mathrm{Cl}$. High $\mathrm{NO}_{3}$ concentrations may also be a consequence of the disposal of human waste which would act overall to concentrate $\mathrm{Cl}$. Some correlation of high groundwater $\mathrm{NO}_{3}$ and $\mathrm{Cl}$ concentrations is seen in the samples included in Table 1 but as stated in section 4.1, to reduce uncertainty, groundwaters with $\mathrm{NO}_{3}-\mathrm{N}$ concentrations of greater than $20 \mathrm{mg} \mathrm{l}^{-1}$ were removed from dataset used in the CMB.

v) Rainfall and runoff $\mathrm{Cl}$ concentrations. Although the rainfall $\mathrm{Cl}$ concentration used in the mass balance is the average of three years weighted mean this is comparable with other long term values measured elsewhere across Africa (inland site, N. Nigeria $1.4 \mathrm{mg} \mathrm{l}^{-1}$, Edmunds et al, 1999; coastal site, Senegal $2.8 \mathrm{mg} \mathrm{l}^{-1}$, Edmunds and Gaye, 1994). The mass balance has assumed runoff $\mathrm{Cl}$ concentration is the same as that of precipitation. The small amount of runoff $\mathrm{Cl}$ data do not allow a weighted mean $\mathrm{Cl}$ mass 
to be calculated for this component of the water balance but what are available show concentrations in runoff from both sub-catchments greater than that of rainfall. The uncertainty in this component of the $\mathrm{CMB}$ is significant for the absolute values of recharge estimated. A higher $\mathrm{Cl}$ concentration in runoff than rainfall would result in a ratio of recharge to the mafic rocks and felsic rocks higher than estimated in Section 4.3.

vi) Recharge mechanisms. As has been reported elsewhere in semi-arid regions of Africa (Favreau et al, 2009; Taylor et al, 2013), Butterworth et al (1999b) identified that in the Romwe catchment a high proportion of groundwater recharge occurred as a result of intense rainfall events, in part because sufficient water was delivered to the soil to overcome the moisture deficit and allow rapid percolation of water below the root zone. They also identified that recharge was enhanced on the upgradient side of field bunds where runoff is captured during intense rainfall. This recharge mechanism fits the assumptions of the $\mathrm{CMB}$, with the $\mathrm{Cl}$ mass being conserved in the evaporating standing water. The spatial variability in groundwater $\mathrm{Cl}$ may be partially related to changes in density of bunds within the cultivated area; it may also be due to enhanced recharge where the hillslopes meet the relatively flat gradient of the valley floor. However, the mean $\mathrm{Cl}$ concentration used assumes that water samples are representative of groundwater chemistry.

Interflow through the sandy horizon than overlies the clay layer in the regolith of the felsic rock group has been observed to enter directly into large-diameter wells. As this water may otherwise have remained at depths where evapotranspiration could take place, this direct inflow would result in sampling of groundwater that is not representative of the aquifer. $\mathrm{Cl}$ concentrations in groundwater in these wells are likely to be lower than those in the aquifer. The recharge to the felsic rock group could therefore be even less than estimated.

Given the range of potential errors and the lack of data to quantify them, it has not been possible to define error bounds for the estimates of groundwater recharge calculated using the CMB. Comparison with those estimates produced by physical methods does, however, does provide some confidence that the estimates from the CMB are of the correct order. Further, were the areas of uncertainty listed above to be addressed then the conclusion that recharge to the mafic rock aquifer is substantially greater than to the felsic rock aquifer would not change. The occurrence of natural vegetation likely to concentrate $\mathrm{Cl}$ does not vary between the areas underlain by the two soil/aquifer types in Romwe. The influence of current land use on comparative recharge rates was also considered. Butterworth et al (1999a) identify differences in cultivation between the two soil types in the Romwe Catchment as a result of the ease of ploughing and the drainage characteristics and it is accepted that this has an influence. However, walking surveys showed that in Greater Romwe the intensity of cultivation was much lower than in Romwe but still the correlation between CMBderived recharge rates and soil/aquifer type is apparent, although not so strong. In Romwe, the areas of the two main soil types are fully cultivated and there is no indication of a difference in organic matter application. As identified above, if $\mathrm{Cl}$ concentrations in runoff are higher than assumed then this would increase the ratio of mafic to felsic aquifer recharge.

\subsection{Conceptual model of groundwater flow system}

A conceptual model of the dynamics of the groundwater systems in the low-lying areas of the catchment has water moving into the mafic aquifer more quickly causing water levels to rise rapidly but, due to higher permeability, recessing to relatively low levels during the dry season. The higher recharge, storage and permeability make it significantly more productive than the felsic rock aquifer. Less water is able to replenish the felsic rock aquifer system due to higher runoff on the grey duplex soils and the poorer infiltration capacity of the underlying aquifer. Lower overall permeability of the aquifer means less recession but also greater drawdown in wells in response to pumping, as well as lower yields.

Groundwater $\mathrm{Cl}$ concentrations in the mafic aquifer remained uniform over the 1995/96 season in which there was regular monitoring of selected wells; this implies a large degree of aquifer homogeneity. It is likely, therefore, that the recharge signature is made-up principally of direct recharge via permeable soils to a uniform aquifer, rather than mixing in a dual porosity or layered system, for example. During the wetter years of the 18-year rainfall cycle in southern Africa, groundwater levels in the mafic aquifer often return to close to the ground surface during the wet season indicating a rapid response under the low storage 
conditions (Butterworth et al, 1999c). The most likely mechanism for this, based on the monitored $\mathrm{Cl}$, is direct infiltration via the permeable soils displacing water from storage as a pressure response to the incoming groundwater.

During the drier periods of the 18-year cycle the lower rainfall results in lower recharge and a greater buildup of $\mathrm{Cl}$ as a result of evapotranspiration. Although there may be slight variations in groundwater $\mathrm{Cl}$ concentrations in the aquifer over the whole 18-year cycle, a large degree of homogenisation is expected to take place.

The above model also applies to the felsic rock aquifer where the slow movement of recharging water has further buffered the fluctuations in groundwater $\mathrm{Cl}$. The time series data show there is a trend towards higher $\mathrm{Cl}$ and changes in the groundwater chemistry in wells and piezometers within the felsic rock aquifer within a season. This, it is thought, is due to the greater effect of interflow as a recharge source. This has implications for the conclusions from the results from the Romwe catchment as these were based on samples taken at the beginning of the dry season. If groundwater $\mathrm{Cl}$ concentrations in the wells in the felsic rock aquifer measured in March 1994 were lower than the concentrations in the aquifer distant from the wells, recharge estimates will have been overestimated.

As with the Romwe catchment, the median $\mathrm{Cl}$ concentrations in the samples from the mafic rock aquifer in Greater Romwe were higher than the felsic rock, although with a lower ratio. This suggests that the conceptual model of the groundwater system developed for the Romwe catchment could be applied across Greater Romwe and further extrapolated. There is anecdotal evidence that supports this, as the number and productivity of groundwater points is low in the areas identified from the ground as having grey duplex soils, the opposite being the case in areas with red clay soils.

\section{Conclusions}

1) The geochemical approach adopted in the Romwe Catchment study supports the findings from piezometric evidence and monitoring that there are significant differences in hydrogeological properties of weathered basement derived from different primary lithologies. In particular the recharge rates and well yields are higher in aquifers derived from basic as compared with acidic lithologies.

2) Major ion compositions and several minor ions clearly reflect the weathering of the two main gneiss lithologies and their ratios and concentrations may be used to fingerprint the sources of the groundwater.

3) The hydrochemical signatures correspond closely to the classification of rock types derived from field surveys (Romwe catchment) and satellite images (Romwe and Greater Romwe) and provide confirmation that the latter can be used to define groundwater types in suitable terrain.

4) Chloride acts as an inert tracer (in contrast to water itself which is lost during the evaporation and transpiration process) and has been used here to investigate the water balance, the accumulation of chloride being proportional to evaporative concentration. This has been achieved by measurements of rainfall, and rainfall chemistry, and the chloride concentrations in groundwaters.

5) The chloride mass balance method has been used to estimate groundwater recharge for the Romwe catchment, for the mafic aquifer, $22 \mathrm{~mm}$, and the felsic rock aquifer, $6.7 \mathrm{~mm}$. These are $3.7 \%$ and $1.1 \%$, respectively, of the long-term mean annual rainfall. This compares well with the results of studies on the Romwe catchment using physical techniques. The uncertainties associated with the chloride mass balance-derived recharge estimates although potentially significant have not been quantified. However, there is confidence in the conclusion that the recharge to the mafic aquifer is substantially greater than that to the felsic aquifer.

6) The results obtained by extrapolation from the well-instrumented Romwe catchment to Greater Romwe (with limited data) have allowed upscaling of the experiments.

7) The chloride mass balance may be used as a simple and inexpensive tool to investigate catchment water balances in seasonally arid hard rock terrain such as occur in tropical regions. These methods also apply 
to areas with limited data and where (hydrological) instrumental approaches may be time consuming and implementation costly. However a minimum of rainfall measurement (ideally over several years) and rainfall and groundwater/surface water analyses are required.

The results from this study have implications for groundwater development in basement terrains. Zones identified by remotely sensed images have been linked indirectly to the productivity of the weathered basement aquifer. Properly calibrated, these images could be further regionalized to site groundwater sources, providing a relatively inexpensive development tool.

\section{ACKNOWLEDGEMENTS}

The authors would like to thank colleagues from the British Geological Survey and the Centre of Ecology and Hydrology (formerly the Institute of Hydrology) that helped with field and analytical work in this study, including Patrick Moriarty, Duncan Thompson, John Bromley, John Butterworth, Chris Lovell, Janice Trafford, and Jon Finch. Many thanks also to the people of the Greater Romwe area that helped with data collection. This document is an output from a project funded by UK aid from the UK Department for International Development (DFID) for the benefit of developing countries. The views expressed are not necessarily those of DFID. David Macdonald publishes with the permission of the Executive Director of the British Geological Survey.

\section{REFERENCES}

Acworth, R.I., 1987. The development of crystalline basement aquifers in a tropical environment. Q. J. Eng. Geol. 20, 265-272.

Allison, G.A., Hughes, M.W., 1978. The use of environmental chloride and tritium to estimate total recharge to an unconfined aquifer. Austr. J. Soil Res. 16, 181-195.

Allison, G.B., Gee, G.W., Tyler, S.W., 1994. Vadose-zone techniques for estimating groundwater recharge in arid and semi-arid regions. Soil Sci. Soc. Am. J. 58, 6-14.

Appelo, C.A.J., Postma, D., 2005. Geochemistry, groundwater and pollution. $2^{\text {nd }}$ edition. A.A Balkema, Leiden, The Netherlands.

Bromley, J., Butterworth, J.A., Macdonald, D.M.J., Lovell, C.J., Mharapara, I., Batchelor, C.H., 1999. Hydrological processes and water resources management in a dryland environment I: An introduction to the Romwe Catchment Study in southern Zimbabwe. Hydrol. and Earth Syst. Sci. 3, 321-332.

Butterworth, J.A., 1997. Hydrology of a dryland catchment in southern Zimbabwe and impacts of climate variation and land use on shallow groundwater resources. $\mathrm{PhD}$ thesis, University of Reading, UK.

Butterworth, J.A., Mugabe, F., Simmonds, L.P., Hodnett, M.G., 1999a. Hydrological processes and water resources management in a dryland environment II: Surface redistribution of rainfall within fields. Hydrol. and Earth Syst. Sci. 3, 333-343.

Butterworth, J.A., Macdonald, D.M.J. Bromley, J., Simmonds, L.P., Lovell, C.J., Mugabe, F., 1999 b. Hydrological processes and water resources management in a dryland environment III: Groundwater recharge and recession in a shallow weathered aquifer. Hydrol. and Earth Syst. Sci. 3, 345-352.

Butterworth, J.A., Schulze, R.E., Simmonds, L.P., Moriarty, P.B., Mugabe, F., 1999c. Hydrological processes and water resources management in a dryland environment IV: Long-term groundwater level fluctuations due to variation in rainfall. Hydrol. and Earth Syst. Sci. 3, 353-361.

Chilton, P.J., Foster, S.S.D., 1995. Hydrogeological characterisation and water-supply potential of basement aquifers in tropical Africa. Hydrogeol. J. 3, 36-49. 
Clark, L., 1985. Groundwater abstraction from basement complex areas of Africa. Q. J. Eng. Geol., 18, 2534.

Cowling, R.M., Richardson, D.M., Pierce, S.M., 1997. Vegetation of Southern Africa. Cambridge University Press, Cambridge, UK.

Courtois, N., Lachassagne, P., Wyns, R., Blanchin, R., Bougaïré, F.D., Somé, S., Tapsoba, A., 2010. Largescale mapping of hard-rock aquifer properties applied to Burkina Faso. Ground Water, 48(2), 269-283.

Crosbie, R.S, Binning, P., Jetse, D.K., 2005. A time series approach to inferring groundwater recharge using the water table fluctuation method. Wat. Resour. Res., 41(1), W01008.

Edmunds, W.M., Andrews, J.N., Burgess, W.G., Kay, R.L.F., Lee, D.J., 1984. The evolution of saline and thermal groundwaters in the Carnmenellis granite. Mineralogical Magazine, 48(348), 407-424.

Edmunds, W.M., Darling, W.G., Kinniburgh, D.G., 1988. Solute profile techniques for recharge estimation in semi-arid and arid terrain. In: I Simmers (Ed), Estimation of natural groundwater recharge. NATO ASI Series C, 222. Proceedings of NATO Advanced Research Workshop, Antalya, Turkey, March 1987. Reidel, Dordrecht, 139-157.

Edmunds, W.M., Fellman, E., Goni, I.B., 1999. Lakes, groundwater and palaeohydrology in the Sahel of NE Nigeria: evidence from hydrogeochemistry. J. Geol. Soc. London, 156, 345-355.

Edmunds, W.M., Gaye, C.B., 1994. Estimating the spatial variability of groundwater recharge in the Sahal using chloride. J. Hydrol., 156, 47-59.

Edmunds, W. M., Gaye, C.B., 1997. "Naturally high nitrate concentrations in groundwaters from the Sahel." J. Env. Quality, 26(5), 1231-1239.

Edmunds, W.M., Walton, N.R.G., 1980. A geochemical and isotopic approach to recharge evaluation in semi-arid zones - past and present. In: Arid Zone Hydrology: Investidations with Isotpoic Techniques, 4768, IAEA, Vienna.

Eriksson, E., 1976. The distribution of salinity in groundwaters in the Delhi region and recharge rates of groundwater. In. "Interpretation of Environmental and Isotopic Hydrochemical Data in Groundwater Hydrology". IAEA, Vienna. pp 171-178.

Eriksson, E., Khunakasem, V., 1969. Chloride concentrations in groundwater, recharge rate and rate of deposition of chloride in the Israel coastal plain. J. Hydrol., 7, 178-197.

Favreau, G.G., Cappelaere, B., Massuel, S., Leblanc, M., Boucher, M., Boulain, N., Leduc, C., 2009. Land clearing, climate variability, and water resources increase in semiarid southwest Niger: a review. Wat. Resour. Res., 45(7), W00A16.

Fookes, P.G., 1997. Tropical Residual Soils. Geological Society Publishing House, Bath, UK, 184p.

Foster, S.S.D., Chilton, P.J., Moench, M., Cardy, F., Schiffler, M., 2000. Groundwater in rural development. World Bank Technical Paper 463, The World Bank, Washington DC.

Gates, J.B., Edmunds, W.M., Jinzhu, Ma, Scanlon, B.R., 2008. Estimating groundwater recharge in a cold desert environment in northern China using chloride. Hydrogeol. J. 16, 893-910.

Gaye, C.B., Edmunds, W.M., 1996. Groundwater recharge estimation using chloride, stable isotopes and tritium profiles in the sands of north-west Senegal. Environ. Geol. 27. 246-251.

JMP, 2008. Global Water Supply and Sanitation 2008 Report, Joint Monitoring Programme WHO/UNICEF, World Health Organization, Geneva. 
Jones, M.J., 1985. The weathered zone aquifers of the basement complex areas of Africa. Q. J. Eng. Geol. $18,35-46$.

Kamineni, D. C., 1987. Halogen-bearing minerals in plutonic rocks: a possible source of chlorine in saline groundwater in the Canadian Shield. Saline water and gases in crystalline rocks. Geol. Assoc. Can. Spec. Pap., $33,69-79$.

Lapworth, D.J., MacDonald, A.M., Tijani, M.N., Darling, W.G., Gooddy, D.C., Bonsor, H.C., Araguás-Araguás, L. J., 2013. Residence times of shallow groundwater in West Africa: implications for hydrogeology and resilience to future changes in climate. Hydrogeol. J., DOI 10.1007/s10040-012-0925-4.

Lerner, D.N., Issar, A.S., Simmers, I., 1990. Groundwater recharge - a guide to understanding and estimating natural recharge. Vol. 8. Internat. Assoc. Hydrogeol. Hanover.

Macdonald, D.M.J., Thompson, D.M., Herbert, R., 1995. Sustainability of yield from wells and boreholes in crystalline basement aquifers. BGS Technical Report WC/95/50.

MacDonald, A.M., Bonsor, H.C., Ó Dochartaigh, B.E., Taylor, R.G., 2012. Quantitative maps of groundwater resources in Africa. Environ. Res. Lett. 7 (2), 024009, $7 \mathrm{pp}$.

MacDonald, A.M., Calow, R.C., Macdonald, D.M.J., Darling, W.G., Ó Dochartaigh, B.E., 2009. What impact will climate change have on rural groundwater supplies in Africa? Hydrol. Sci. J. 54 (4). 690-703. doi: 10.1623/hysj.54.4.690

MacDonald, A.M., Davies, J., Calow, R.C., Chilton, P.J., 2005 Developing groundwater: a guide for rural water supply. Rugby, UK, ITDG Publishing, 358pp.

Malomo, S., Okufarasin, V.A., Olorunniwo, M.A. and Omode, A.A., 1990. Groundwater chemistry of weathered zone aquifers of an area underlain by basement complex rocks. J. Afr. Earth Sci., 11, 357-371.

Moriarty, P.B., 2000. Integrated catchment management and sustainable water resource development in semi-arid Zimbabwe. PhD thesis, University of Reading.

Mugabe, F., Hodnett, M.G., Senzanje, A., Gonah, T., 2007. Spatio-temporal rainfall and runoff variability of the Runde Catchment, Zimbabwe, and implications on surface water resources. Afr. Water J. 1(1), 66-79.

Phillips, F.M., 1994. Environmental tracers for water movement in desert soils of the American South West. Soil Sci. Soc. Amer. J., 58, 14-24.

Raveh, E., Levy, Y., 2005. Analysis of xylem water as an indicator of current chloride uptake status in citrus trees. Sci. Hort., 103(3), 317-327.

Robertson, I.D.M., 1974. Explanation of the geological map of the country south of Chibi. Zimbabwe Geological Survey Short Report No.41, pp 40.

Rocchio, L. (The Landsat Program web site curator, National Aeronautics and Space Administration, USA), 2011, The Landsat Program, viewed 7 March 2011, http://landsat.gsfc.nasa.gov/.

Scanlon, B.R., Keese, K.E., Flint, A.L., Flint, L.E., Gaye, C.B., Edmunds, W.M., Simmers, I., 2006. Global synthesis of groundwater recharge in semi-arid and arid regions. Hydrol. Processes, 20, 3335-3370.

Simmers, I. (Ed), 1988. Estimation of natural groundwater recharge. NATO ASI Series C, 222, (Proc. NATO Advanced Research Workshop, Antalya, Turkey, March 1987). D. Reidel, Dordrecht. 
Stadler, S., Osenbrück, K., Duijnisveld, W.H.M., Schwiede, M., Böttcher, J., 2010. Linking chloride mass balance infiltration rates with chloroflurocarbon and SF6 groundwater dating in a semi-arid setting: potential and limitations. Isot. Environ. Health Studies, 46 (3), 312-324.

Sukhija, B.S., Reddy, D.V., Nagabhushanam, P., Chand, R., 1988. Validity of environmental chloride method for recharge evaluation of coastal aquifers, India. J. Hydrol., 99, 349-366.

Taylor, R.G., Howard, K.W.F., 1995. Groundwater quality in rural Uganda: hydrochemical considerations for the development of aquifers within the basement complex of Africa. In: J. McCall and H. Nash (Ed.s), Groundwater Quality, 31-43. Chapman \& Hall Ltd, London, UK.

Taylor, R.G., Howard, K.W.F.,. 2000. A tectono-geomorphic model of the hydrogeology of deeply weathered crystalline rock: Evidence from Uganda. Hydrogeol. J. 3(8), 279-294.

Taylor, R.G., Tindimugaya, C., Barker, J.A., Barrett, M., Macdonald, D.M.J., Kulabako, R., Nalubega, M., Edwardmartin, R., 2010. Convergent radial tracing of viral and solute transport in gneiss saprolite. Ground Water, 48(2), 284-294.

Taylor, R.G., Todd, M.C., Kongola, L., Maurice, L., Nahozya, E., Sanga, H., MacDonald, A.M., 2013. Evidence of the dependence of groundwater resources on extreme rainfall in East Africa. Nature Climate Change, 3, 374-378.

Wood, W.W., Sandford, W.E., 1995. Chemical and isotopic methods for quantifying ground-water recharge in a regional, semiarid environment. Ground Water 33, 458-468.

Wright, E.P., 1992. The hydrogeology of crystalline basement aquifers in Africa. In: The Hydrogeology of Crystalline Basement Aquifers in Africa (ed. Wright and Burgess), Geol. Soc. Spec. Publ. No.66, 1-27. 
Table 2 Calculation of groundwater recharge in the Romwe catchment (standard deviation is given in brackets)

\begin{tabular}{lcccc}
\hline Aquifer & $\begin{array}{c}\text { effective rainfall } \\
(\mathrm{mm})\end{array}$ & $\begin{array}{c}\text { mass of chloride } \\
\text { entering ground } \\
(\mathrm{mg})\end{array}$ & $\begin{array}{c}\text { mean groundwater } \\
\text { chloride } \\
\text { concentration } \\
\left(\mathrm{mg} \mathrm{l}^{-1}\right)^{\mathrm{c}}\end{array}$ & $\begin{array}{c}\text { mean } \\
\text { groundwater } \\
\text { recharge } \\
(\mathrm{mm})\end{array}$ \\
\hline Mafic & $585(250)$ & $523(334)$ & $24(4)$ & $22(14)$ \\
Felsic & $556(238)$ & $497(317)$ & $74(16)$ & $6.7(4.5)$ \\
\hline
\end{tabular}

a effective rainfall is calculated for the two aquifer types by subtracting estimates of runoff for each from the long term average rainfall. Runoff is estimated using the ratio of rainfall to runoff measured for the 1994/95 wet season for the two representative sub-catchments

b mass of chloride entering ground is calculated by multiplying the effective rainfall by the weighted mean rainfall chloride concentration over the wet seasons 1993/94, 1994/95, 1995/96 which is $0.89 \mathrm{mg} \mathrm{l}^{-1}$ (SD $0.42 \mathrm{mg} \mathrm{l}^{-1}$ )

c mean groundwater chloride concentration is calculated by interpolation onto a regular grid using kriging. Chloride concentrations used are those listed in Table 1, apart from samples that had a NO3-N concentration $>20 \mathrm{mg} \mathrm{I}^{-1}$ 
Table 3

Groundwater chemistry in wells in Greater Romwe, sampled November 1997

\begin{tabular}{|c|c|c|c|c|c|c|c|c|c|c|c|c|c|c|c|c|c|c|c|}
\hline ID & Easting $^{\mathrm{a}}$ & Northing $^{\mathrm{a}}$ & Hole depth & $\mathrm{pH}^{\mathrm{b}}$ & EC & $\mathrm{Na}$ & $\bar{K}$ & $\mathrm{Ca}$ & $\mathrm{Mg}$ & $\mathrm{Cl}$ & $\mathrm{SO}_{4}$ & $\mathrm{HCO}_{3}{ }^{\mathrm{b}}$ & $\mathrm{NO}_{3}{ }^{\mathrm{C}}$ & Si & B & $\mathrm{Sr}$ & $\mathrm{Ba}$ & $\overline{\mathrm{Fe}_{\text {tot }}}$ & \% lonic balance \\
\hline \multicolumn{20}{|c|}{ RED CLAY SOILS } \\
\hline GR01 & 270406 & 7703594 & 6 & 7.12 & 358 & 54.7 & 2.8 & 10.1 & 7.9 & 26 & 1.4 & 171 & $<0.5$ & 27.0 & 0.016 & 0.077 & 0.146 & 4.34 & 0.6 \\
\hline GR07 & 269446 & 7705694 & NM & 6.75 & 655 & 26.9 & 0.48 & 51.5 & 39 & 27 & 21.2 & 313 & 10.2 & 36.9 & 0.036 & 0.111 & 0.012 & 0.09 & -0.8 \\
\hline GR08 & 269026 & 7705874 & 14 & 8.74 & 307 & 42.4 & 1.8 & 14.1 & 5.0 & 16 & 8.1 & 145 & $<0.5$ & 33.9 & 0.014 & 0.074 & 0.095 & 0.03 & 0.0 \\
\hline GR09 & 268396 & 7701974 & 6 & 6.12 & 195 & 19.2 & 1.7 & 7.05 & 5.4 & 31 & 0.7 & 49.2 & $<0.5$ & 18.9 & 0.008 & 0.053 & 0.159 & 0.04 & -0.8 \\
\hline GR10 & 268696 & 7702094 & NM & 5.81 & 54 & 6.4 & 1.4 & 2.25 & 1.4 & 6 & 0.1 & 22.8 & $<0.5$ & 6.6 & 0.005 & 0.028 & 0.111 & 0.43 & 0.4 \\
\hline GR11 & 268846 & 7701824 & 10 & 6.14 & 96 & 9.6 & 1.1 & 3.43 & 2.4 & 7 & 0.1 & 40.3 & $<0.5$ & 9.9 & 0.004 & 0.035 & 0.090 & 0.48 & -1.8 \\
\hline GR12 & 268246 & 7701314 & NM & 5.14 & 54 & 6.7 & 1.2 & 0.68 & 0.7 & 6 & 0.1 & 14.6 & $<0.5$ & 9.6 & 0.003 & 0.010 & 0.049 & 0.16 & -0.1 \\
\hline GR13 & 268786 & 7701464 & 8 & 5.20 & NM & 6.4 & 0.80 & 2.70 & 1.3 & 6 & 0.1 & 18.2 & 0.6 & 9.9 & 0.002 & 0.028 & 0.059 & 0.15 & 2.0 \\
\hline GR14 & 266476 & 7705844 & NM & 6.76 & NM & 34.1 & 0.37 & 26.0 & 26.3 & 39 & 11.0 & 225 & 0.7 & 34.2 & 0.019 & 0.133 & 0.025 & 0.04 & -1.2 \\
\hline GR15 & 266566 & 7705844 & NM & 7.09 & 490 & 36.0 & 1.3 & 27.6 & 27.0 & 41 & 10.9 & 171 & $<0.5$ & 33.0 & 0.018 & 0.152 & 0.099 & 0.03 & 10.7 \\
\hline GR18 & 269266 & 7707554 & NM & 7.37 & 1773 & 210 & 2.8 & 45.5 & 92.8 & 243 & 8.9 & 726 & 12.7 & 33.5 & 0.049 & 0.382 & 0.315 & 0.04 & -1.9 \\
\hline GR30 & 273106 & 7700924 & NM & 6.60 & 355 & 30.1 & 0.32 & 19.2 & 14.8 & 23 & 1.0 & 173 & $<0.5$ & 31.2 & 0.009 & 0.141 & 0.050 & 2.82 & -0.3 \\
\hline GR31 & 273226 & 7702664 & NM & 6.72 & 366 & 16.2 & 0.80 & 38.6 & 17.7 & 30 & 4.6 & 170 & 5.3 & 35.2 & 0.014 & 0.112 & 0.025 & 0.16 & 0.2 \\
\hline GR32 & 275206 & 7704944 & NM & 7.11 & 347 & 39.8 & 0.16 & 11.0 & 12.6 & 20 & 1.2 & 148 & 4.8 & 35.8 & 0.015 & 0.095 & 0.115 & 0.16 & -0.4 \\
\hline GR33 & 271366 & 7700324 & 5 & 6.41 & 262 & 26.0 & 3.3 & 11.1 & 6.1 & 43 & 4.4 & 60.7 & $<0.5$ & 13.2 & 0.006 & 0.085 & 0.228 & 0.07 & -0.6 \\
\hline GR34 & 270106 & 7699994 & NM & 5.58 & 117 & 8.6 & 0.70 & 4.21 & 2.6 & 12 & 0.6 & 22.7 & 1.0 & 13.1 & 0.002 & 0.023 & 0.032 & 0.03 & 0.8 \\
\hline GR35 & 269596 & 7699814 & NM & 5.71 & 100 & 8.8 & 0.60 & 4.88 & 4.3 & 11 & 0.45 & 40.0 & $<0.5$ & 18.5 & 0.005 & 0.023 & 0.040 & 0.04 & 2.2 \\
\hline GR36 & 268696 & 7698224 & NM & 6.70 & 370 & 61.1 & 1.0 & 9.34 & 9.6 & 16 & 20.3 & 192 & $<0.5$ & 33.6 & 0.010 & 0.104 & 0.038 & 0.09 & -1.0 \\
\hline GR37 & 290026 & 7698434 & NM & 5.31 & 78 & 9.8 & 1.4 & 1.74 & 0.9 & 9 & 0.31 & 17.8 & 0.6 & 10.5 & 0.003 & 0.020 & 0.046 & 0.30 & 3.3 \\
\hline GR38 & 267286 & 7695524 & NM & 6.66 & 396 & 67.0 & 0.29 & 9.96 & 11.4 & 13 & 4.9 & 236 & 1.0 & 37.1 & 0.023 & 0.050 & 0.022 & 0.18 & -0.8 \\
\hline GR39 & 267886 & 7696754 & NM & 6.88 & 340 & 14.2 & 0.50 & 17.6 & 16.0 & 17 & 2.7 & 150 & $<0.5$ & 13.6 & 0.010 & 0.097 & 0.142 & 1.03 & -2.7 \\
\hline GR40 & 274036 & 7699394 & NM & 6.32 & 210 & 21.6 & 0.17 & 9.44 & 4.9 & 17 & 5.9 & 77.5 & $<0.5$ & 16.2 & 0.010 & 0.042 & 0.057 & 0.53 & -1.8 \\
\hline GR41 & 273196 & 7696574 & NM & 5.82 & 108 & 13.2 & 1.1 & 4.70 & 2.2 & 10 & 0.6 & 40.5 & 0.5 & 12.2 & 0.004 & 0.043 & 0.058 & 0.23 & 2.6 \\
\hline GR46 & 269566 & 7704404 & 6 & 6.33 & 212 & 21.6 & 0.70 & 9.57 & 4.9 & 25 & 0.7 & 60.5 & 1.8 & 12.5 & 0.009 & 0.086 & 0.091 & 0.09 & 0.0 \\
\hline GR47 & 263446 & 7706594 & NM & 6.78 & 690 & 89.5 & 0.70 & 16.1 & 23.7 & 89 & 10.6 & 248 & $<0.5$ & 27.9 & 0.030 & 0.175 & 0.135 & 0.04 & -1.1 \\
\hline GR49 & 273466 & 7705664 & NM & 6.46 & 154 & 11.0 & $<0.5$ & 8.38 & 4.5 & 12 & 1.0 & 31.5 & 6.6 & 14.1 & 0.014 & 0.053 & 0.094 & $<0.02$ & -2.5 \\
\hline GR51 & 273766 & 7701134 & NM & 6.44 & 432 & 25.3 & 0.60 & 28.8 & 18.6 & 35 & 6.1 & 143 & 9.0 & 26.5 & 0.012 & 0.269 & 0.212 & $<0.02$ & -0.1 \\
\hline GR55 & 272146 & 7701854 & NM & 5.70 & 121 & 13.0 & $<0.5$ & 4.29 & 2.2 & 17 & $<0.5$ & 11.4 & 3.6 & 11.9 & 0.012 & 0.048 & 0.188 & 0.26 & 2.3 \\
\hline \multirow[t]{2}{*}{ R03 } & 266836 & 7703774 & 8.4 & 6.90 & 309 & 16.7 & 1.4 & 21.9 & 13.6 & 10 & 5.0 & 110 & 12.3 & 23.4 & 0.014 & 0.050 & 0.055 & 0.02 & -1.7 \\
\hline & & Median & & 6.46 & 307 & 21.6 & 0.80 & 9.96 & 6.1 & 17 & 1.4 & 110 & 0.5 & 18.9 & 0.010 & 0.074 & 0.090 & 0.09 & \\
\hline \multicolumn{20}{|c|}{ GREY DUPLEX SOILS } \\
\hline GR02 & 270166 & 7703684 & 3 & 7.35 & 404 & 63.4 & 3 & 21.9 & 6.3 & 67 & 4 & 143 & $<0.5$ & 6.4 & 0.015 & 0.146 & 0.462 & 0.54 & 1.3 \\
\hline GR04 & 270256 & 7704434 & NM & 6.99 & 852 & 52.8 & 1.6 & 76.5 & 39.8 & 89 & 20.4 & 389 & $<0.5$ & 29.4 & 0.013 & 0.241 & 0.389 & 0.05 & 0.6 \\
\hline GR05 & 265966 & 7702904 & NM & 6.58 & 176 & 15.5 & 0.9 & 12.8 & 4.1 & 25 & 2.2 & 56.2 & $<0.5$ & 20.1 & 0.010 & 0.089 & 0.124 & 0.08 & 0.5 \\
\hline GR06 & 264436 & 7703114 & 14 & 7.45 & 866 & 51.8 & 0.6 & 65.5 & 28.8 & 108 & 18.8 & 224 & 13.2 & 18.8 & 0.011 & 0.326 & 0.187 & $<0.02$ & -0.9 \\
\hline GR16 & 267976 & 7708454 & NM & 7.19 & 976 & 122 & 0.46 & 48.3 & 40.4 & 24 & 2.8 & 648 & $<0.5$ & 19.9 & 0.051 & 0.215 & 0.006 & 0.03 & -1.3 \\
\hline GR17 & 270016 & 7708754 & NM & 7.85 & 1454 & 272 & 1.1 & 17.5 & 24.3 & 217 & 0.24 & 539 & $<0.5$ & 6.4 & 0.031 & 0.196 & 0.096 & 0.12 & -0.8 \\
\hline GR24 & 260986 & 7702304 & NM & 7.15 & 977 & 118 & 0.6 & 49.2 & 60.2 & 84 & 7.5 & 628 & 0.6 & 26.0 & 0.045 & 0.279 & $<0.003$ & 0.02 & -1.2 \\
\hline GR27 & 270346 & 7708544 & NM & 6.42 & 121 & 16.7 & 1.8 & 1.72 & 2.3 & 15 & 2.7 & 30.4 & $<0.5$ & 20.3 & 0.009 & 0.024 & 0.128 & 2.60 & 3.7 \\
\hline GR28 & 272236 & 7708454 & NM & 7.17 & 1390 & 211 & 0.8 & 43.1 & 64 & 166 & 3.8 & 695 & 4.0 & 27.0 & 0.083 & 0.274 & 0.063 & $<0.02$ & 0.5 \\
\hline GR43 & 269656 & 7703984 & 10 & 7.13 & 520 & 81.3 & 1.6 & 18.6 & 18.5 & 46 & 3.7 & 282 & $<0.5$ & 22.4 & 0.016 & 0.193 & 0.598 & 0.24 & 0.3 \\
\hline GR45 & 271066 & 7702874 & NM & 6.77 & 265 & 25.5 & 3.9 & 13.8 & 7.1 & 22 & 0.5 & 113 & $<0.5$ & 28.0 & 0.548 & 0.129 & 0.170 & 0.55 & 0.3 \\
\hline GR48 & 275086 & 7707374 & NM & 6.54 & 140 & 14.7 & $<0.5$ & 5.85 & 3.6 & 13 & $<0.5$ & 52.7 & $<0.5$ & 5.7 & 0.004 & 0.084 & 0.187 & 0.09 & 0.5 \\
\hline GR50 & 272866 & 7705064 & 4.5 & 6.24 & 116 & 11.0 & $<0.5$ & 3.28 & 1.9 & 19 & $<0.5$ & 13.2 & $<0.5$ & 7.1 & 0.009 & 0.048 & 0.236 & 0.18 & 2.4 \\
\hline GR52 & 269116 & 7696394 & NM & 5.00 & 117 & 14.8 & 1.7 & 0.77 & 0.7 & 11 & 0.6 & 36.6 & $<0.5$ & 14.3 & 0.009 & 0.010 & 0.063 & 0.35 & -8.2 \\
\hline GR54 & 272506 & 7703114 & 3 & 6.55 & 183 & 20.9 & 0.6 & 7.44 & $\begin{array}{l}3.1 \\
3.1\end{array}$ & 24 & 4.4 & 50.5 & $<0.5$ & 13.5 & 0.012 & 0.068 & 0.173 & 0.33 & -1.0 \\
\hline \multirow[t]{2}{*}{ R18 } & 268396 & 7703804 & 9.3 & 7.02 & 118 & 40.9 & 1.1 & 19.2 & 15.6 & 47 & 4.2 & 162 & 0.7 & 22.6 & 0.021 & 0.104 & 0.159 & 0.03 & -0.7 \\
\hline & & Median & & 7.01 & 335 & 40.9 & 0.9 & 17.5 & 7.1 & 36 & 3.5 & 143 & $<0.5$ & 20.1 & 0.013 & 0.129 & 0.159 & 0.09 & \\
\hline
\end{tabular}

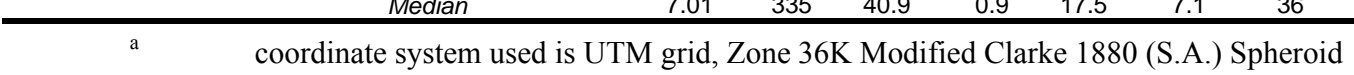




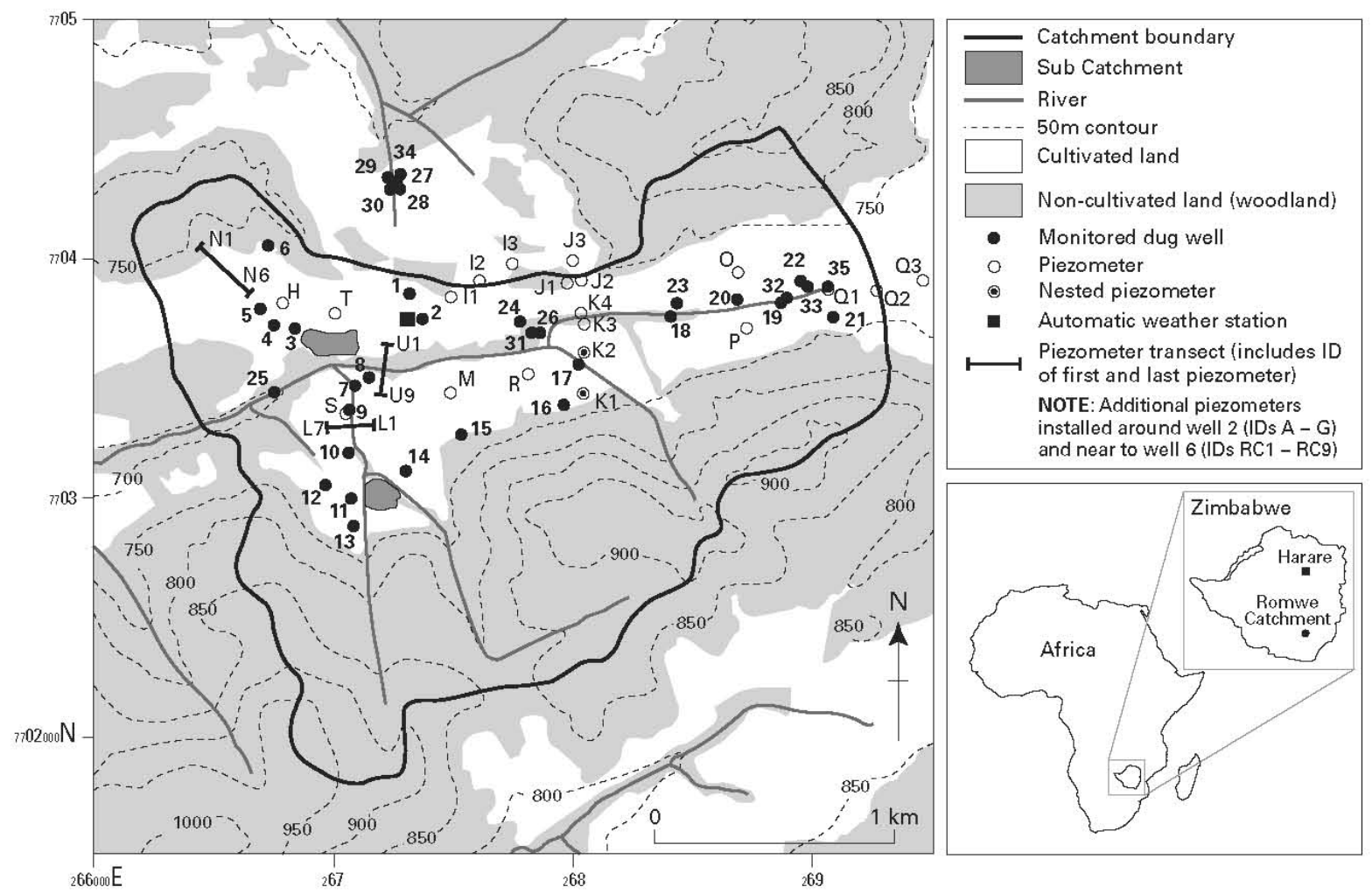

Figure 1 Romwe Catchment, topography, hydrology, land use and location of wells and piezometers. Coordinate system used is UTM grid, Zone 36K Modified Clarke 1880 (S.A.) Spheroid. 

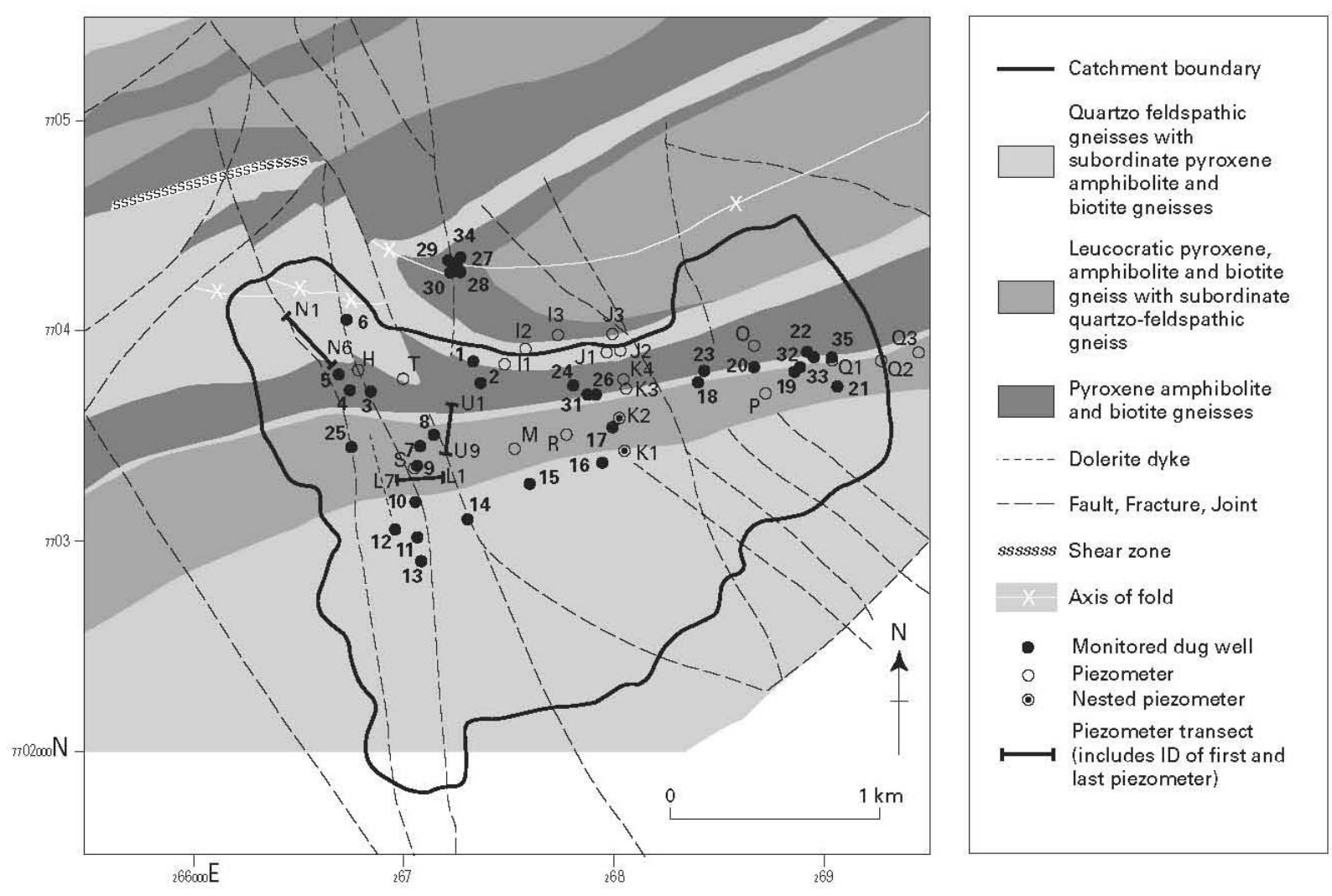

Figure 2 Romwe Catchment geology. After Bromley et al (1999), accessed under the Creative Commons Attribution-NonCommercial-ShareAlike 2.0 Generic licence (CC-BY-NCSA 2.0). Quartzo feldspathic and leucocratic gneisses together are referred to as the felsic rock group; the pyroxene amphibolites and biotite gneiss is referred to as the mafic rock. Coordinate system used is UTM grid, Zone 36K Modified Clarke 1880 (S.A.) Spheroid. 


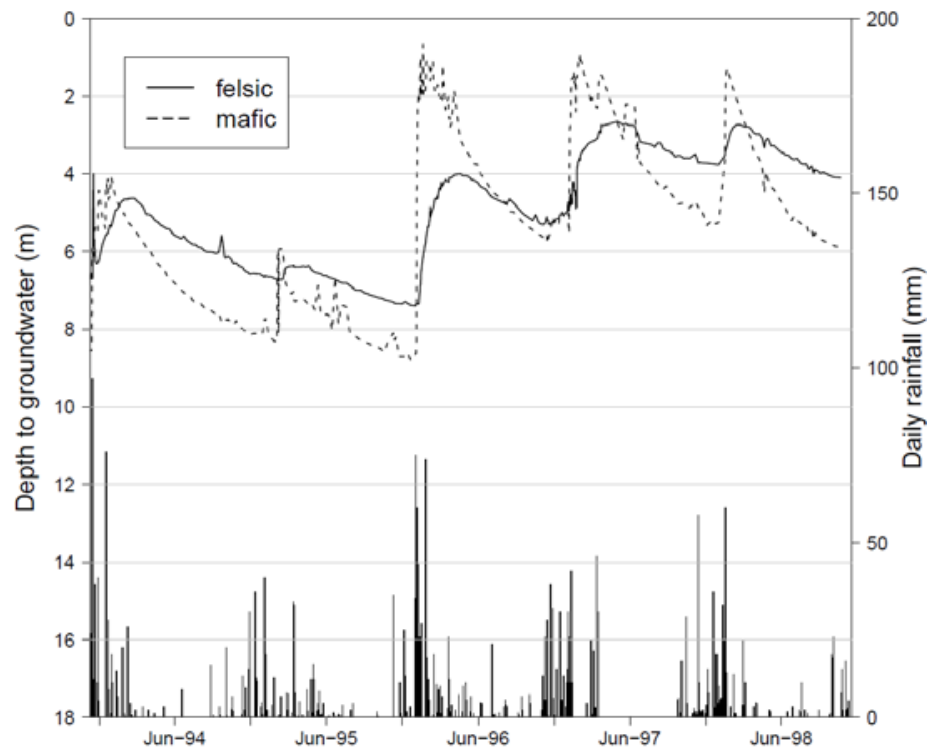

Figure 3 Rainfall in the Romwe catchment and typical groundwater hydrographs for the mafic gneiss aquifer (piezometer $\mathrm{G}$ ) and the felsic rock group aquifer (piezometer K2). Note, the spikiness of the hydrograph may be partially due to the lack of casing in the piezometers below 1 metre, allowing ingress of infiltrating rainfall via preferential flow pathways in the unsaturated zone. 

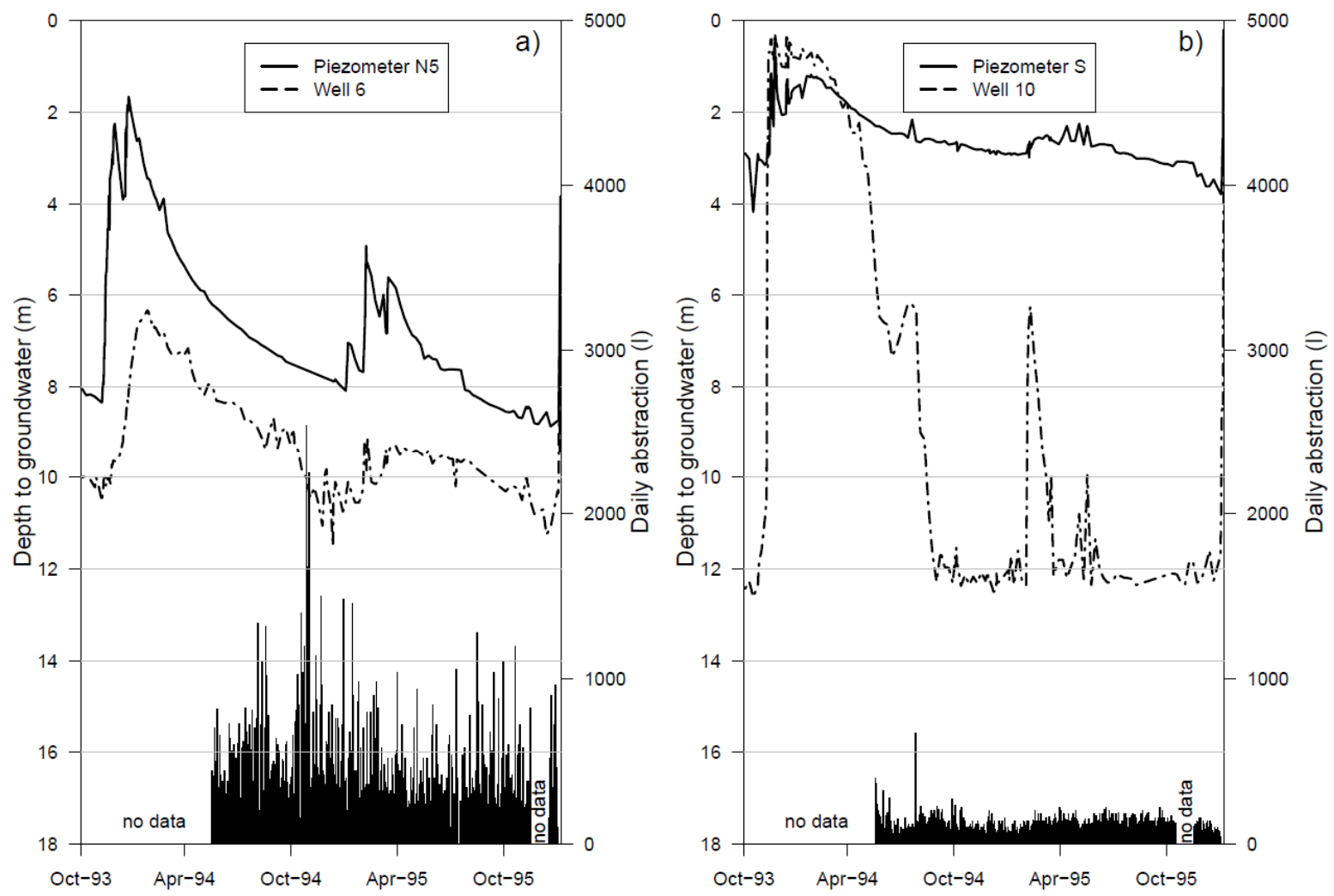

Figure $4 \quad$ Groundwater levels in wells and nearby piezometers in the mafic (a) and felsic (b) rocks, with weekly abstraction volumes (litres), for 1994/95 dry season. Note, the spike in the water level for Well 10 in January 1995 is thought to be due to interflow directly recharging the well following a rainfall event. 


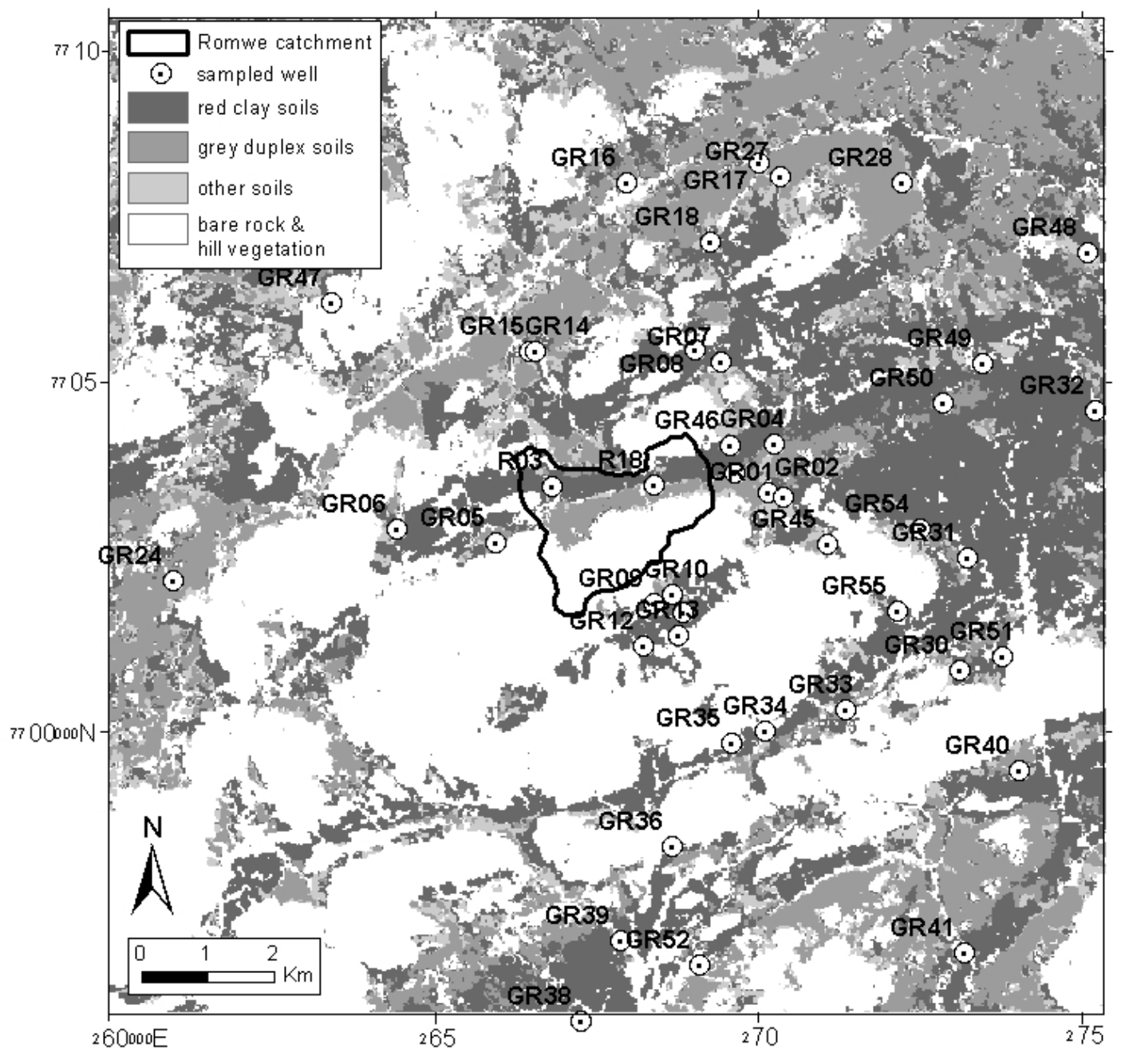

Figure 5 Greater Romwe area showing soils, derived from a Landsat image (1992), and wells included in the groundwater sampling round. Landsat imagery courtesy of NASA Goddard Space Flight Center and U.S. Geological Survey. Pixel size, 30 metres. Coordinate system used is UTM grid, Zone 36K Modified Clarke 1880 (S.A.) Spheroid. 


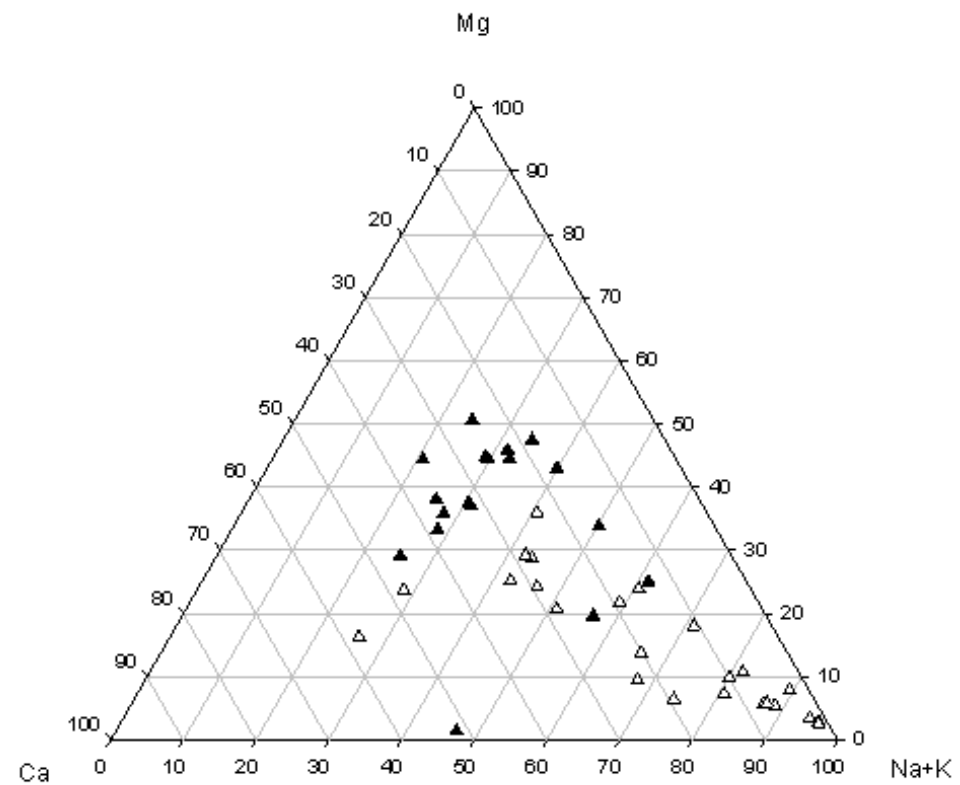

Figure 6 Trilinear plot summarising inorganic chemistry of groundwater samples from Romwe catchment. Samples from groundwater sources in mafic rock are shown by solid symbols and in felsic rocks are open symbol. 

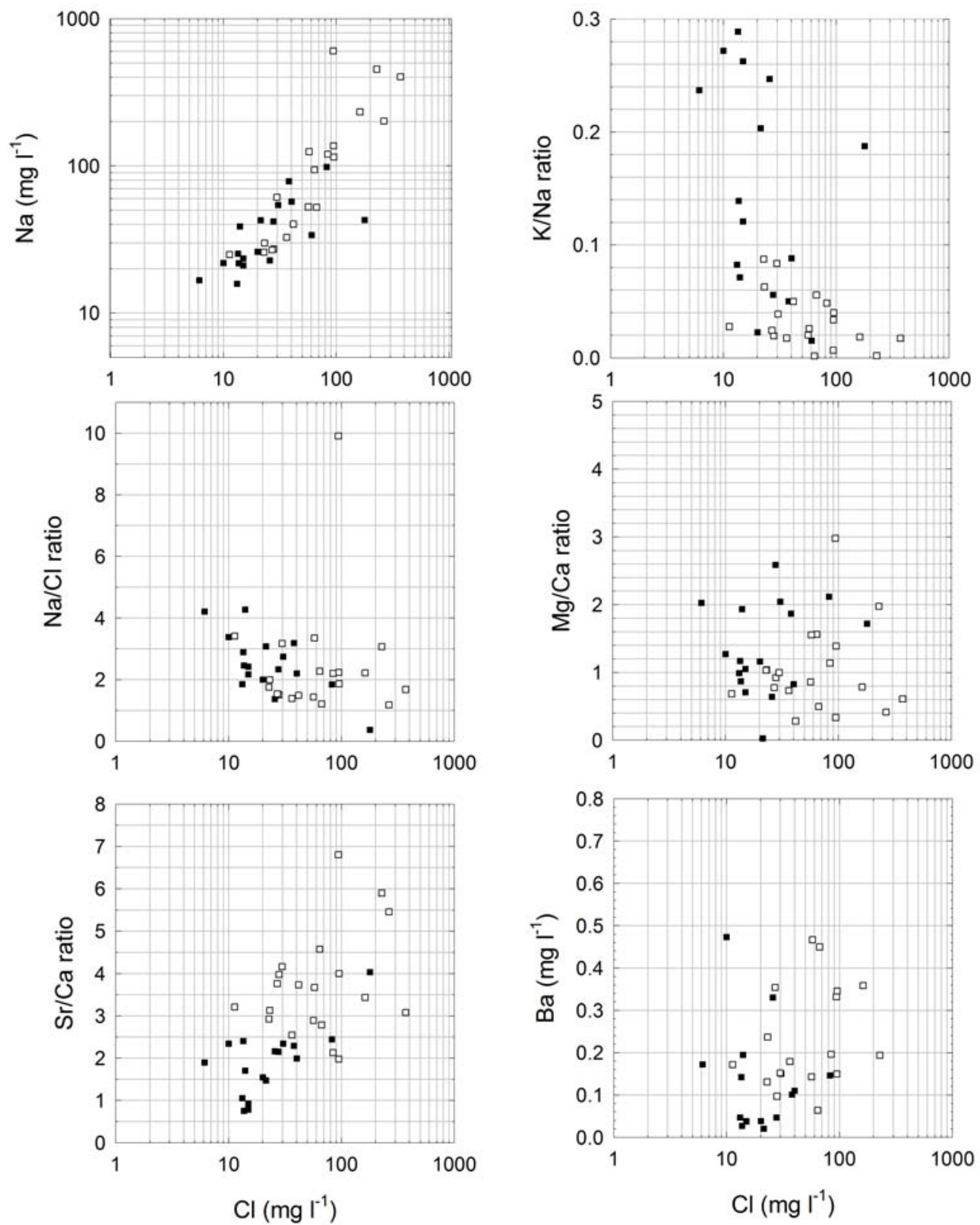

Figure 7 Ions and ionic ratios $(\mathrm{Na}, \mathrm{Na} / \mathrm{Cl}, \mathrm{K} / \mathrm{Na}, \mathrm{Mg} / \mathrm{Ca}, \mathrm{Sr} / \mathrm{Ca}$ and $\mathrm{Ba}$ ) versus chloride in groundwaters from Romwe Catchment, sampled March 1994. Samples from groundwater sources in mafic rock are shown by solid symbols and in felsic rocks are open symbols 

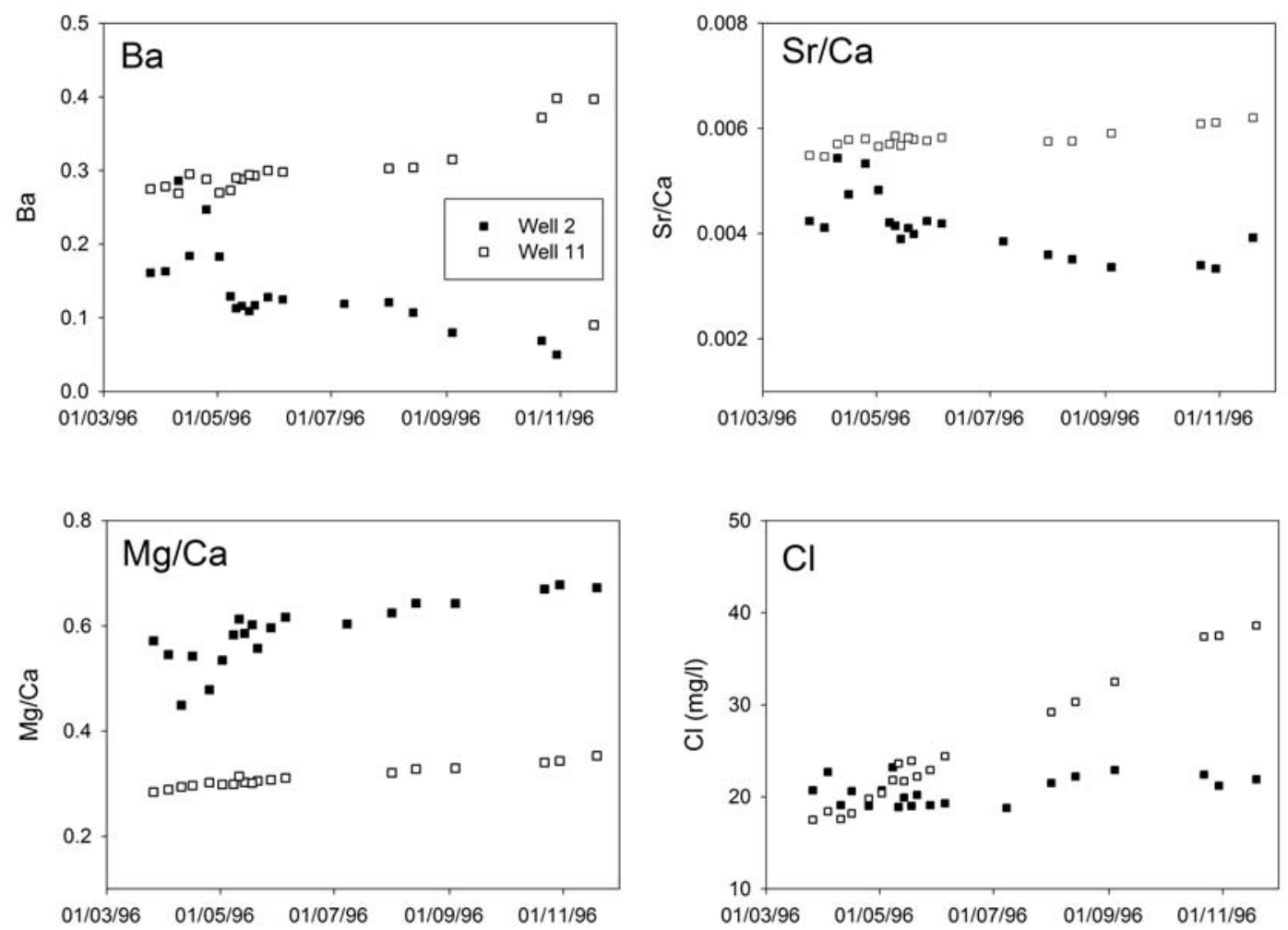

Figure 8 Ion and ionic ratio variation $(\mathrm{Ba}, \mathrm{Sr} / \mathrm{Ca}, \mathrm{Mg} / \mathrm{Ca}$ and $\mathrm{Cl})$ over the 1995/96 dry season in groundwater samples from Romwe catchment. Well 11 is in the felsic rock and Well 2 is in the mafic rock. 

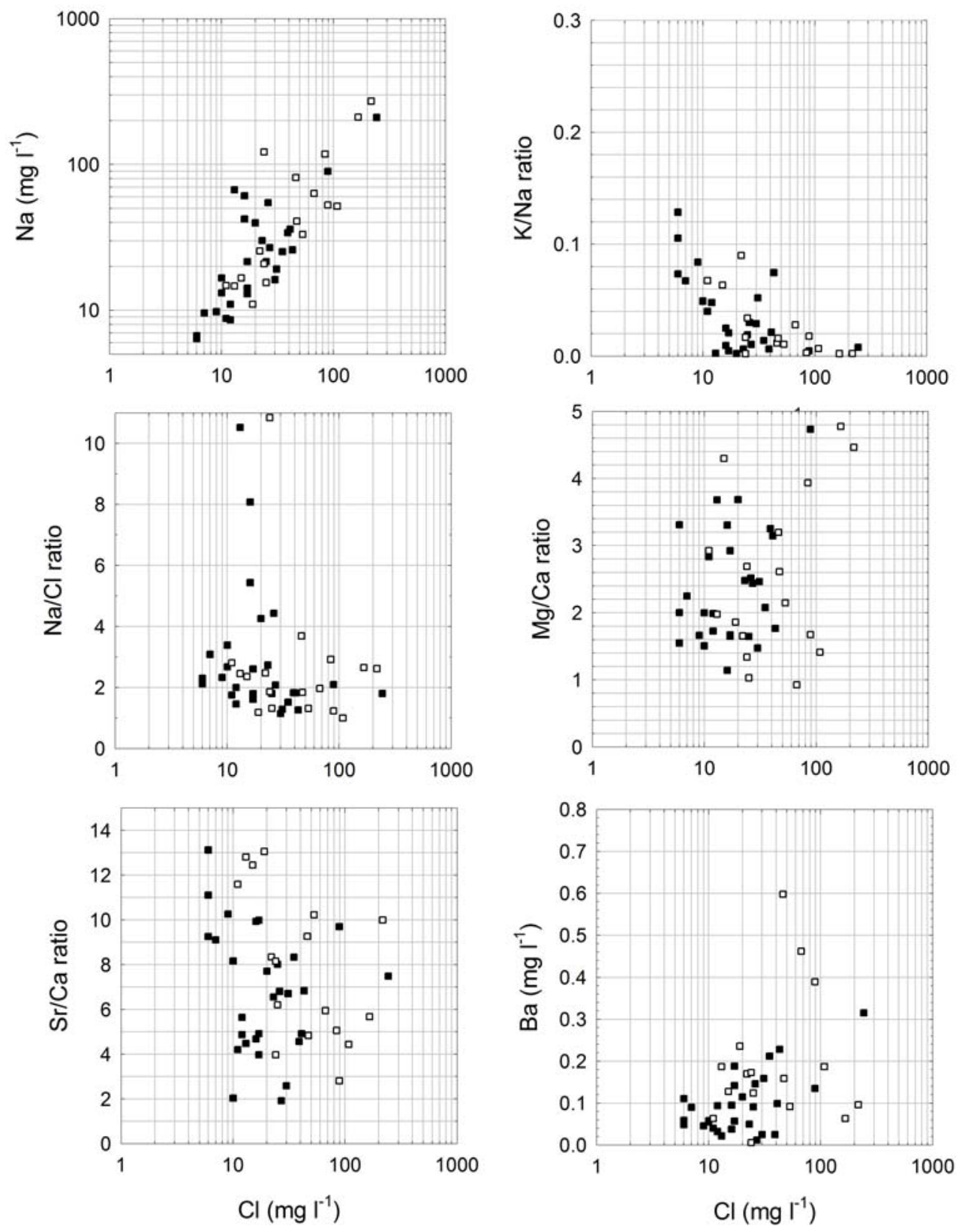

Figure 9 Ions and ionic ratios $(\mathrm{Na}, \mathrm{Na} / \mathrm{Cl}, \mathrm{K} / \mathrm{Na}, \mathrm{Mg} / \mathrm{Ca}, \mathrm{Sr} / \mathrm{Ca}$ and $\mathrm{Ba})$ versus chloride in groundwater samples from Greater Romwe, sampled November 1997. Samples from groundwater sources in mafic rock are shown by solid symbols and in felsic rocks are open symbols. 